\title{
REMOVAL JURISDICTION AND THE ALL WRITS ACT
}

\author{
LONNY SHEINKOPF HOFFMAN $^{\dagger}$
}

\section{INTRODUCTION}

On February 5, 1998, United States District Judge Samuel B. Kent denied the plaintiffs' motion to remand in Chance v. Sullivan, ruling that the All Writs Act ${ }^{2}$ could serve as an independent basis for removal where the plaintiffs' state claims threatened to interfere with a prior federal order. ${ }^{3}$ This decision should be remarkable to most students of federal civil procedure, since the complaint did not raise a federal question and there was no diversity of citizenship between the parties. Yet, in making the determination that the All Writs Act could be used to remove an otherwise unremovable case, Judge Kent added his voice to a small but growing chorus of federal circuit and district court judges who have upheld use of this extraordinary writ for this extraordinary purpose.

Although the All Writs Act traces its lineage back to the Judiciary Act of $1789,{ }^{4}$ for nearly two hundred years no court ever relied on

† Visiting Assistant Professor of Law, University of Cincinnati College of Law. B.A. 1989, Columbia College, Columbia University; J.D. 1992, University of Texas School of Law. I am greatly indebted to Stephen Burbank, Henry Monaghan, Michael Solimine, and Gabriel J. Chin for their invaluable time and comments.

993 F. Supp. 565 (S.D. Tex. 1998).

228 U.S.C. § 1651(a) (1994). Section 1651(a), known as the All Writs Act, provides: "The Supreme Court and all courts established by Act of Congress may issue all writs necessary or appropriate in aid of their respective jurisdictions and agreeable to the usages and principles of law."

${ }^{3}$ See Chance, 993 F. Supp. at 567-68 ("Alternatively, the Court has jurisdiction of the claims against Sullivan by virtue of the All Writs Act....").

4 The statutory ancestors of $\S 1651$ (a) are sections 13 and 14 of the Judiciary Act of 1789. Judiciary Act of 1789 , ch. 20, $\$ \S 13-14,1$ Stat. 73, 81-82 (1789). The language of section 14 substantially mirrors that which is contained in the present version of 28 U.S.C. $\S 1651$ (a). Section 14 of the Judiciary Act of 1789 provided, in part:

And be it further enacted, That all the before-mentioned courts of the United States, shall have power to issue writs of scire facias, habeas corpus, and all other writs not specially provided for by statute, which may be necessary for the exercise of their respective jurisdictions, and agreeable to the principles and usages of law.

Id. at 82. 
$\S 1651$ (a) to ground its jurisdiction over a case removed from state to federal court. Indeed, the most common use of the statute has been in mandamus proceedings, in which the All Writs Act underlies the court's appellate jurisdiction. ${ }^{5}$ Congress also authorized district courts to invoke $\S 1651$ (a), ${ }^{6}$ but it was not until 1988 that a court first approved use of the All Writs Act as an independent basis for removal.

In section 13 of the Act, Congress also empowered the Supreme Court "to issue writs of prohibition to the district courts, when proceeding as courts of admiralty and maritime jurisdiction, and writs of mandamus, in cases warranted by the principles and usages of law, to any courts appointed, or persons holding office, under the authority of the United States." Id. at 81. Professors Wright, Miller, and Cooper have noted that $\S 1651$ (a)'s roots are in sections 13 and 14 of the First Judiciary Act. See 16 CHARLES ALAN WRIGHT ET AL., FEDERAL PRACTICE AND PROCEDURE § 3933, at 535 (2d ed. 1996) [hereinafter WRIGHT ET AL.] (explaining that " $\$ 1651$ (a) is a combination of two provisions that trace back to sections 13 and 14 of the First Judiciary Act"). The Court and other commentators have identified only section 14 as the source of statutory origin. See Pennsylvania Bureau of Correction v. United States Marshals Serv., 474 U.S. 34, 40 (1985) (remarking that the "All Writs Act originally was codified in $\$ 14$ of the Judiciary Act of $1789^{\prime \prime}$ ); see also Akhil Reed Amar, Marbury, Section 13 and the Original Jurisdiction of the Supreme Court, 56 U. CHI. L. REv. 443, 458 (1989) (observing that section 14 of the First Judiciary Act is "the precursor of today's All Writs Act").

${ }^{5}$ See Ex parte Republic of Peru, 318 U.S. 578, 583 (1943) (finding that " $[\mathrm{t}]$ he historic use of writs of prohibition and mandamus directed by an appellate to an inferior court has been to exert the revisory appellate power over the inferior court"); see generally 19 JAMES WM. MOORE ET AL., MOORE's FEDERAL PRACTICE I 204.01 [2][c] (3d ed. 1997) [hereinafter MOORE ET AL.] (noting that " [t]he most frequently used writ is the writ of mandamus").

${ }^{6} 28$ U.S.C. $\$ 1651$ (a) (1994) ("The Supreme Court and all courts established by Act of Congress may issue all writs necessary ....") (emphasis added); see generally MOORE ET AL., supra note 5, II 204.01[3][b], 204.01[3][c] (observing that the All Writs Act applies to circuit and district courts).

${ }^{7}$ See Yonkers Racing Corp. v. City of Yonkers, 858 F.2d 855, 865 (2d Cir. 1988) ("Accordingly, we hold that removal was proper under the All Writs Act. We do so because removal was necessary to protect the integrity of the Consent Decree and because the issues raised by the Article 78 petitions cannot be separated from the relief provided by the Consent Decree."). In Fidelity Fin. v. Robinson, 971 F. Supp. 244, 246 (S.D. Miss. 1997), one of only two district courts in a reported decision to decline to approve removal under $\$ 1651$ (a), see infra note 33, the court stated that Yonkers was "the earliest reported decision" the court could locate "in which removal was allowed under the authority of the All Writs Act." For a discussion of the Yonkers decision, see infra text accompanying notes 38-59. There is one remarkable Supreme Court of Louisiana decision that antedates Yomkers by eighteen years, in which the subject of removal pursuant to the All Writs Act was discussed, but the propriety of removal under $\$ 1651$ (a) received neither the express approval nor rejection of the court. In Swope $v$. St. Mary Parish Sch. Board, 241 So. 2d 238 (La. 1970), residents of a Louisiana parish, seeking to avoid a school desegregation plan promulgated by a United States district court, petitioned a Louisiana state court to enjoin the local school board from carrying out the federal court's desegregation plan. The United States government, although not a party to the injunction suit, intervened in the action and obtained an order of 
Thereafter, the number of federal district and circuit courts grounding removal in the All Writs Act has grown rapidly. ${ }^{8}$ In the last decade, approximately thirty federal courts have considered, and at least twenty have approved, use of the All Writs Act as an independent basis for removal, principally on the premise that resort to the All Writs Act was necessary to protect or preserve a prior federal judgment. Viewed in historical context, in which no court ever considered $\S 1651$ (a) as removal authority for almost two hundred years, the evidence suggests that these "little clouds" may be bringing a "flood's downpour."

To date, literature regarding this expanded use of the All Writs Act as a source of removal jurisdiction is scarce. ${ }^{10}$ This Article, how-

removal from the federal district court. The Louisiana residents' motion to remand was subsequently denied by the federal court. See Swope, 241 So. $2 d$ at 240 (detailing the procedural history of the case).

The government's removal petition specifically cited 28 U.S.C. $\$ \S 1441,1443$, and 1651 as grounds for removal. See id. at 249 (Summers, J., dissenting) ("[T] he prayer of the 'Petition for Removal and Consolidation' implores the Federal District Court for an order 'Removing to this Court the case of John L. Swope, et al. v. St. Mary Parish School Board, as provided by Title 28 U.S.C. $\$ \S 1441,1443$ and 1651."'). The Louisiana residents never appealed the denial of remand, however. Instead, they "sought a writ of mandamus from the Louisiana Court of Appeal," and when that was denied, from the Louisiana Supreme Court. Id. at 241. One of the arguments they made was that the government had no right to rely on $\S 1441$ since it was not a party defendant to the state injunction action. See id. at 245 (explaining the plaintiffs' arguments under 28 U.S.C. \$1441). In its original opinion, the Louisiana Supreme Court did not address the propriety of removal under the All Writs Act, ruling that the proper procedure to contest removal was by direct appeal of the order denying remand. See id. at 241-42 ("Even if that court erred in entertaining jurisdiction, its determination ... could not be questioned by them ... collaterally, or otherwise than on writ of error or appeal to this court." (internal citation omitted)). Since no appeal was taken, that order became res judicata and could not be attacked collaterally. See id. (noting that when a federal district court has ruled on an issue, that judgment "remains in effect until reversed on appeal or on a writ of error to the proper federal appellate tribunal"). In its subsequent opinion after rehearing, the court affirmed its prior holding that by not directly appealing the denial of remand, the Louisiana residents could not collaterally attack that judgment. See id. at 246 ("The prior federal judgment of dismissal, resultant from the federal court's denial of the plaintiffs' motion to remand, is now a definitive judgment, since not appealed and no longer appealable." (internal citation omitted)). Thus, the Swope court never addressed whether the All Writs Act could serve as an independent basis for removal jurisdiction.

${ }^{8}$ See generally infra Part II (discussing cases in which the All Writs Act has been invoked to support removal).

${ }^{9}$ Cf. La Buy v. Howes Leather Co., 352 U.S. 249, 258 (1957) (approving a writ of mandamus to vacate a district court order which referred an antitrust case to a master where the district judge had previously referred eleven cases to masters over a period of six years and observing that even "a little cloud may bring a flood's downpour" (internal citation omitted in original)).

${ }^{10}$ One of the few commentators to focus any analytical attention on the All Writs 
ever, undertakes a critical examination of the use of the All Writs Act as removal authority and reaches two chief conclusions. First, the All Writs Act was not intended to serve as an independent basis of jurisdiction over a case removed from state to federal court. Like its much younger sister, the Supplemental Jurisdiction Statute, ${ }^{11}$ the All Writs

Act as a source of removal authority is Professor Henry Monaghan of Columbia University. In an article principally examining the binding effects of a trial court's class action judgment on nonresident class members, Professor Monaghan considers the use of the All Writs Act to establish in personam jurisdiction over such class members. See Henry Paul Monaghan, Antisuit Injunctions and Preclusion Against Absent Nonresident Class Members, 98 CoLUM. L. REv. 1148, 1187-91 (1998). He concludes-rightly, in my view-that the All Writs Act "cannot provide an independent basis for in personam jurisdiction over nonresident class members in mass and toxic tort cases who have been "conscripted' into the class action." Id. at 1190-91. See also ChARLes AlAN WRIGHT \& JOHN B. OAKLEY, FEDERAL COURTS 256 n.14 (10th ed. 1999) (recognizing a circuit split on the issue of whether the All Writs Act "ever authorize[s] the removal of state-court litigation to prevent direct conflict with orders of a district court in the conduct of related federal litigation").

${ }^{11} 28$ U.S.C. $\$ 1367$ (1993). The Supplemental Jurisdiction Statute was codified by Congress in section 310 of the Judicial Improvements Act of 1990. See Pub. L. No. 101650, 104 Stat. 5089, 5113-14 (1990) ("Chapter 85 of title 28, United States Code, is amended by adding at the end thereof the following new section: $\S 1367 . ")$. Section 1367 consistently has been held not to be a source of original subject matter jurisdiction and, therefore, insufficient to support removal of a case from state to federal court. See Ahearn v. Charter Township, 100 F.3d 451, 456 (6th Gir. 1996) (ruling that the "supplemental-jurisdiction statute is not a source of original subject-matter jurisdiction, and a removal petition therefore may not base subject-matter jurisdiction on the supplemental-jurisdiction statute" (internal citation omitted)); Frankenberg v. Superior Distribs., Inc., 961 F. Supp. 1560, 1566 (S.D. Ala. 1997) ('To accept Plaintiffs' basis for establishing subject matter jurisdiction, in my opinion, would extend the doctrine of supplemental jurisdiction too broadly ...."); Parker v. Crete Carrier Corp., 914 F. Supp. 156, 159 (E.D. Ky. 1996) ("Supplemental jurisdiction cannot destroy the requirement for complete diversity ...."); Sebring Homes Corp. v. T.R. Arnold \& Assocs., Inc., 927 F. Supp. 1098, 1101 (N.D. Ind. 1995) ("The supplemental jurisdiction statute does not confer original jurisdiction on claims or suits."); In re Estate of Tabas, 879 F. Supp. 464, 467 (E.D. Pa. 1995) (holding that "the supplemental jurisdiction statute does not allow a party to remove an otherwise unremovable action to federal court" and that the "statute is not ... an independent source of removal jurisdiction"); Zewe v. Law Firm of Adams \& Reese, 852 F. Supp. 516, 520 (E.D. La. 1993) (observing that "a district court does not have supplemental jurisdiction under 28 U.S.C. $\$ 1367$ to entertain the merits of claims in a state court suit which was removed without original jurisdiction"); Holt v. Lockheed Support Sys., Inc., 835 F. Supp. 325, 329 (W.D. La. 1993) ("Defendant's application of 28 U.S.C. $\$ 1367$ would impermissibly broaden this court's removal jurisdiction ...."); see also 13B CHARLES ALAN WRIGHT ET AL., FEDERAL PRACTICE AND PROCEDURE $\$ 3567.3$, at 63 (2d ed. Supp. 1999) ("The supplementaljurisdiction statute is not a source of original jurisdiction and a case cannot be brought or removed on grounds of supplemental jurisdiction alone."). In Avitts v. Amoco Prod. Co., 53 F.3d 690, 694 (5th Cir. 1995), the Fifth Circuit declined to exercise federal removal jurisdiction under $\S 1367$. The Court found no subject matter jurisdiction over the case and ordered it remanded: 
Act is not a source of original jurisdiction. ${ }^{12}$ Federal courts are courts of limited jurisdiction because they cannot assume jurisdiction over a particular controversy unless it comes within Article III of the Constitution and a specific statute permits them to exercise jurisdiction. ${ }^{13}$ However, Congress has never authorized such an expansive grant of jurisdiction to the federal courts through the All Writs Act. ${ }^{14}$ Consequently, broadening removal jurisdiction in this fashion expands district court original jurisdiction beyond the maximum limits currently authorized by Congress. ${ }^{15}$

This provision [28 U.S.C. $\$ 1367$ (c) (3)] is plainly inapplicable because, by its terms, it presupposes that the district court obtained supplemental jurisdiction over the state law claims via original jurisdiction over federal claims arising from the same case or controversy. As stated above, the district court has never had original jurisdiction over any of the claims in this action because no federal claims have ever been asserted.

Id. at 693.

${ }^{12}$ See infra text accompanying notes 139-69 (discussing the historical evidence that suggests that the power to issue writs was intended to be derivative of jurisdiction previously established).

${ }^{13}$ See Owen Equip. \& Erection Co. v. Kroger, 437 U.S. 365, 372 (1978) ("Constitutional power is merely the first hurdle that must be overcome in determining that a federal court has jurisdiction over a particular controversy. For the jurisdiction of the federal courts is limited not only by the provisions of Art. III of the Constitution, but also by Acts of Congress."); see also 13 CHARLES ALAN WRIGHT ET AI., FEDERAI PRACIICE AND PROCEDURE $\$ 3522$, at 60 (2d ed. 1984) (explaining that federal courts "are empowered to hear only those cases that (1) are within the judicial power of the United States, as defined in the Constitution, and (2) that have been entrusted to them by a jurisdictional grant by Congress").

"Congress has never exercised its authority to vest the full extent of the "judicial power" of Article III in the federal courts. See RICHard H. Fallon, JR. ET AL., HarT AND WECHSLER'S THE FEDERAL COURTS AND THE FEDERAL SYSTEM 349-50 (4th ed. 1996) [hereinafter HART \& WECHSLER] (cataloguing some of the "historical exclusions" limiting the grant of "the entire "judicial [p]ower" to the federal courts).

${ }^{15}$ I do not address here the question whether Congress could ever expand the original jurisdiction of the federal courts under Article III so broadly as to permit removal of any state case which implicates a prior federal judgment. It has long been an accepted maxim that Congress is without power to expand the original jurisdiction of the lower federal courts beyond Article III. See Hodgson v. Bowerbank, 9 U.S. (5 Cranch) 303 (1809) ("[T] he statute cannot extend the jurisdiction beyond the limits of the [C]onstitution."). But, given the expansive scope of Article III judicial power as interpreted by Osborn v. Bank of the United States, 22 U.S. (9 Wheat.) 738 (1824), it could be argued that if a federal judgment may be affected by a subsequent state case, even if the potential impact is unlikely or remote, some "ingredient" of federal law is involved, and therefore, the entire case, including supplemental, nonfederal issues, may be within the jurisdiction of the federal courts. See id. at 823 (ruling "that when a question to which the judicial power of the Union is extended by the [C] an ingredient of the original cause, it is in the power of Congress to give the [c]ircuit [c]ourts jurisdiction of that cause ${ }^{n}$ ). Cf. Textile Workers Union v. Lincoln Mills, 353 
The second primary conclusion of this Article is that the expansive use of the All Writs Act as a source of removal jurisdiction interferes with the balance of state and federal relations in a manner which neither Congress nor the Supreme Court has approved or likely would approve. Congress and the Court have promulgated legal rules and judicial doctrines, respectively, which must be considered when a federal judgment is implicated in subsequent state proceedings. ${ }^{16}$ Courts and litigants must turn to these different legal rules and judicial doctrines to answer whether and when federal intervention is appropriate to protect and effectuate the prior federal judgment. For instance, the doctrine of res judicata is one principal method by which a prior federal judgment is protected in subsequent state actions and may obviate the need for federal intervention into state court proceedings.

Of course, these legal authorities do not represent a single, cohesive or collective unit: they were enacted and promulgated at different times and not always for the same purposes. As a result, judicial application of these disparate legal rules and judicial doctrines may not-indeed, frequently will not-reveal a clear-cut choice for deference or for interference. Judicial expansion of the All Writs Act as an independent removal authority may be explained, in large part, by the Court's and Congress's inability to articulate coherent, consistent guidelines to assess when federal intervention is appropriate and when it is not. Moreover, there is certainly not universal agreement over how each of these authorities should be applied. In effect, disagreement exists over how much freedom the state courts should possess to render decisions that may impact on federal law and federal

U.S. 448, 471 (1957) (Frankfurter, J., dissenting) (commenting on the scope of federal jurisdiction observed in Osborm and stating that federal question jurisdiction "has such flexibility that Congress may confer it whenever there exists in the background some federal proposition that might be challenged, despite the remoteness of the likelihood of actual presentation of such a federal question"). I am not convinced that such a broad reading of Article III is proper. The notion that a state case could be brought into federal court merely by virtue of the fact that the case may, even if only in a minor way, implicate a prior federal judgment would seem to stretch Article III beyond any recognizable limits. Because my argument in this Article is that no implementing statute confers such sweeping jurisdiction on the federal courts, it is not necessary to address this theoretical argument. I reserve for another time the question whether Congress could ever, pursuant to Article III, enable federal courts to hear any state case in which a prior federal judgment might be implicated.

${ }^{16}$ See infra text accompanying notes 194-214 (discussing some of the legal rules and judicial doctrines which may be relevant when a federal judgment is implicated in subsequent state proceedings). 
judgments. ${ }^{17}$ Notwithstanding such difficulties and doctrinal shortcomings, these are the legal authorities to which courts and litigants must turn to answer whether and when federal intervention is appropriate.

In Part III, I attempt to demonstrate that when removal of a state case on the authority of the All Writs Act is upheld, the federal court has interfered in state proceedings without reference to, and possibly in defiance of, the existing legal rules and judicial doctrines promulgated by Congress and the Court. Through this examination, I seek to reestablish that $\S 1651$ (a) is only a general statutory enabling power to the federal courts and that, properly applied, the All Writs Act should be invoked not as a source of removal authority but, in appropriate cases only, to support a federal court's issuance of injunctive or other similar relief. In this manner, the All Writs Act will work in concert with existing procedural alternatives for protecting federal judgments and will lend congruity to, and minimize disharmony between, federal and state systems.

\section{USE OF THE ALL WRITS ACT AS A BASIS FOR REMOVAL}

In Chance $v$. Sullivan, a group of plaintiffs brought suit in Texas state court against the counsel who had previously represented them in a mass toxic tort chemical contamination case. ${ }^{18}$ Judge Kent had also presided over the mass tort action, known as the Phillips case, and had approved a settlement in the case which finally disposed of the protracted litigation. ${ }^{19}$ After the settlement was reached, twenty-two of

${ }^{17}$ See infra text accompanying note 202 (highlighting the continuing debate over the proper division of power between federal and state court).

993 F. Supp. 565, 567 (S.D. Tex. 1998).

${ }^{19}$ See id. at 567 (stating that the court in Phillips had found that the settlement agreement was made in good faith). The Phillips litigation had an "extremely protracted" history: suit was originally filed in 1992 and settlement was reached in September 1995 and finally approved by the court by written order on October 17, 1996. See Plaintiffs' Original Petition at 4-5, Chance v. Sullivan, 993 F. Supp. 565 (S.D. Tex. 1998) (No. 97-48182) (copy on file with author) (detailing the history of the underlying suits); see also Defendants' Response to Plaintiffs' Motion to Remand at 2, Chance v. Sullivan, 993 F. Supp. 565 (S.D. Tex. 1998) (No.G-97-282) (copy on file with author) (noting that the vast majority of plaintiffs in the underlying suit, including the plaintiffs in the present case, accepted the settlement matrix approved by the court). By reopening the issues in the case, the plaintiffs further elongated the case's duration, a point emphasized by the court in its decision. See id. at 567 (observing that the "underlying litigation in this case began almost six years ago and has been an extremely protracted, extraordinarily burdensome affair"). 
the nearly two hundred original Phillips plaintiffs (all of whom had already "signed releases and received settlement checks" ${ }^{20}$ ) brought suit in Texas state district court against their former lawyers. ${ }^{21}$ The plaintiffs alleged, among other things, that their former counsel had misrepresented the actual settlement value. ${ }^{22}$ Specifically, the plaintiffs alleged that their former counsel had failed to disclose that certain expenses had been deducted from the full settlement fund, ${ }^{23}$ that expert fees had been improperly overstated, that there had been other improper distributions from the proceeds, and that counsel had wrongfully "padded or inflated their out-of-pocket expenses. ${ }^{24}$

The defendants removed the case pursuant to 28 U.S.C. $\$ 1441$, asserting that "federal question jurisdiction exists under 28 U.S.C. $\$ 1331 .{ }^{25}$ The court denied the plaintiffs' motion to remand on two grounds. First, the court found removal proper because "the state claims are inescapably infused with the overriding federal concerns that were the basis of [the] Plaintiffs' causes of action in Phillips.",26

${ }^{20}$ Plaintiffs' Original Petition at 5, Chance v. Sullivan, 993 F. Supp. 565 (S.D. Tex. 1998) (No. 97-48182) (copy on file with author).

${ }^{21}$ See Chance, 993 F. Supp. at 567 ("In this action against Defendants[,] ... Plaintiffs bring causes of action for breach of fiduciary duty, common law fraud and fraud in the inducement, conversion, legal malpractice, and violations of the Texas Deceptive Trade Practices Act.").

${ }^{22}$ See id. ("[T]he allegations... will entail an inextricably intertwined analysis of the propriety of the ... settlement agreement in Phillips.").

${ }^{23}$ See id. ("The Plaintiffs allege... that Defendants failed to disclose that the settlement amount in Phillips was 'actually much higher' than two million dollars ....").

${ }^{24} \mathrm{Id}$.

${ }^{25} I d$. Defendants removed the case to the Houston Division of the Southern District of Texas. The case was then consolidated into the prior toxic tort case in Judge Kent's court in the Galveston Division. See id. at 566-67 (describing the procedural background of the case). By this procedural consolidation of the case, the judge who originally approved the settlement of the federal toxic tort case also decided the propriety of removal of the malpractice action. See id. at 567 (describing how the allegations in this case require an intricate analysis of the settlement agreement "submitted for approval, and indeed approved, by this federal court"). No diversity of citizenship existed in the case as Texas residents were on both sides of the case; therefore, 28 U.S.C. $\S 1332$ was not available as a ground for retaining jurisdiction. See Order of February 5, 1998 at 2, Chance v. Sullivan, 993 F. Supp. 565 (S.D. Tex. 1998) (No. G-97282) (copy on file with author) (noting that the case was removed pursuant to $\S 1331$ ). The sole question before the court was whether federal question jurisdiction existed by virtue of the allegations raised by plaintiffs in their state court petition. See id. at 569 (considering plaintiffs' argument that the case should be remanded to state court as no federal question was presented).

${ }^{26} I d$. at 567. Although the court did not cite any authorities in support of its assertion, an existing body of law known as the ancillary jurisdiction doctrine provides that a court has inherent power to protect its prior judgments. The Supreme Court deci- 
This notion that the common law ancillary jurisdiction doctrine may serve as a basis for exercising removal jurisdiction could be considered novel enough. ${ }^{27}$ The court found a second, independent ground for

sion commonly cited in support of this ancillary jurisdiction doctrine is Local Loan Co. v. Hunt, 292 U.S. 234 (1934). According to Local Loan, a federal court has ancillary jurisdiction "to secure or preserve the fruits and advantages of a judgment or decree rendered therein." 292 U.S. at 239. Over the century, numerous courts have followed Local Loan to protect prior federal judgments, including several prominent Fifth Circuit decisions on which Judge Kent could have relied. See, e.g., Southmark Properties v. Charles House Corp., 742 F.2d 862, 868 (5th Cir. 1984) (observing that "[i]t is well settled ... that a district court possesses ancillary jurisdiction "to secure or preserve the fruits and advantages of a judgment or decree rendered' by that court" (quoting Local Loan, 234 U.S. at 239)).

Today, the doctrines of pendent and ancillary jurisdiction are generally regarded as having been largely, if not entirely, subsumed by codification of the Supplemental Jurisdiction Statute, 28 U.S.C. \$ 1367. See, e.g., Royal Ins. Co. of Am. v. Quinn-L Capital Corp., 3 F.3d 877, 881 n.2 (5th Cir. 1993) (observing that "[w] hat was referred to formerly as 'ancillary jurisdiction' is now included within the category of 'supplemental jurisdiction"). Section 1367 was enacted by Congress in section 310 of the Judicial Improvements Act of 1990. See Pub. L. No. 101-650, 104 Stat. 5089, 5113-14 (1990) (amending the United States Code to provide federal courts with supplemental jurisdiction).

The extent to which the ancillary jurisdiction doctrine may still exist remains uncertain, however. In several post-1993 decisions, the Supreme Court has continued to refer to the doctrine of ancillary jurisdiction. See Peacock v. Thomas, 516 U.S. 349, 354 n.5 (1996) (observing that "Congress codified much of the common-law doctrine of ancillary jurisdiction as part of 'supplemental jurisdiction' in 28 U.S.C. $\$ 1367$ " (emphasis added)). The Court makes other references besides this rather inscrutable remark in the footnote from Peacock, which suggest that $\$ 1367$ did not entirely merge ancillary jurisdiction with supplemental jurisdiction. The body of the Court's decision cites its earlier holding in Kokkonen v. Guardian Life Ins. Co. of Am., 511 U.S. 375 (1994), recognizing that at least some version of the ancillary jurisdiction doctrine still exists. See Peacock, 516 U.S. at 354 (listing circumstances wherein a federal court may exercise ancillary jurisdiction). The Court failed to mention the supplemental jurisdiction statute in its opinion.

Thus, the lower courts continue to conclude that when they retain continuing supervisory powers over a case, it is pursuant to their ancillary jurisdiction power. The Ninth Circuit recently held, for instance, that the district court possesses the power to supervise the fees paid to class counsel, as such power is within the court's ancillary equitable jurisdiction, and indeed even has a duty to exercise such power when no class member has standing to object to the fee structure under Article III. See Zucker v. Occidental Petroleum Corp., No. 97-56270, 1999 WL 842304, at *4 (9th Cir. Oct. 19, 1999) (noting that it was within the "overall supervisory responsibility" of the district court to decide upon the reasonableness of the attorneys' fees settlement, even if no party had objected). As the court noted, "[n]o Article III case or controversy is needed with regard to attorneys' fees as such, because they are but an ancillary matter over which the district court retains equitable jurisdiction even when the underlying case is moot." Id.

${ }^{27}$ Although numerous courts before 1993 had invoked the doctrine of ancillary jurisdiction in the context of issuing injunctive relief, only a few attempted to base re- 
removal in the All Writs Act. ${ }^{28}$ Relying on one Second Circuit decision
that approved removal on the basis of $\S 1651(a),{ }^{29}$ the court held that

moval jurisdiction on it. See Southmark Properties, 742 F.2d at 862 (ruling that the district court had federal jurisdiction to enjoin the state court action under the doctrine of ancillary jurisdiction). One of the few decisions other than Chance to attempt to base removal jurisdiction on the ancillary jurisdiction doctrine is Villarreal v. Brown Express, Inc., 529 F.2d 1219 (5th Cir. 1976). In Villarreal, the plaintiff had initiated suit in federal district court for injuries he sustained in a trucking accident. 529 F.2d at 1220 (detailing the background of the case). The suit was settled and the court signed an accompanying order of dismissal with prejudice. Seven days after the order of dismissal was entered, the plaintiff filed a multi-million dollar suit in Texas state court against the same defendant, alleging that the defendant's conversion and destruction of a critical piece of evidence had forced him to settle his case for substantially less than he otherwise would have settled. See id. (stating that appellant believes he is entitled to an additional $\$ 1$ million for the conversion of the evidence and $\$ 5$ million in punitive damages). The defendant removed the case to federal court on the basis of ancillary jurisdiction. Recognizing the state court case as a direct attack on the federal judgment, the Fifth Circuit upheld the denial of plaintiff's motion to remand. Seeid. at 1221 (finding that the district court properly exercised removal jurisdiction). The most significant finding emphasized by the court in its holding was that the plaintiff's state court claim was "essentially one to recover additional damages for personal injuries, and can be viewed as an action which attacks the order of dismissal entered by the district court in the prior suit between these parties." Id.

At least one significant distinction exists between reliance on the ancillary jurisdiction doctrine as a basis for removal (as exemplified by Villarreal and Chance) and the use of the All Writs Act as an independent basis for removal. In both Villarreal and Chance, the plaintiff filed suit originally in federal court, lost in federal court, and then attempted to seek relief in a state forum. The plaintiff's choice to initiate suit in federal court, thereby electing to litigate in the federal forum, has been considered a critical fact by other courts in interpreting Villarreal See, e.g., Edegbele v. Texaco Overseas Petroleum Co., 840 F. Supp. 448, 452 (E.D. Tex. 1994) (stating that "plaintiff's election of forums by suing in federal court" is one of two justifications for use of the artful pleading doctrine (quoting Sullivan v. First Affiliated Sec., Inc., 813 F.2d 1368 (9th Cir. 1987))). Arguably, where a plaintiff has chosen to litigate in federal court and loses, that court does possess ancillary jurisdiction to prevent the plaintiff from seeking to avoid that judgment. However, the plaintiff may be thwarted from pursuing vexatious litigation either by issuing a contempt order, if the court's original order is broad enough to provide for such relief, or by simply issuing an injunction to prevent the attempted future prosecution of a lawsuit which has been previously resolved by the federal court. See, e.g., Wood v. Santa Barbara Chamber of Commerce, 705 F.2d 1515,1525 (9th Cir. 1983) (affirming issuance of an injunction order to thwart the filing of vexatious litigation).

${ }_{23}$ See Chance, 993 F. Supp. at 568 (holding that under the All Writs Act, the federal district court has subject matter jurisdiction over a claim related to a case previously settled by the court).

${ }^{29}$ See Ivy v. Diamond Shamrock Chems. Co., 996 F.2d 1425, 1431 (2d Cir. 1993) [hereinafter Agent Orange II] (holding that " [a] district court ... may use its All Writs Act authority to remove an otherwise unremovable state court case"). The Agent Or. ange II matter developed from an attempt to reopen the mass Agent Orange litigation that resulted from the consolidation to the Eastern District of New York, and subse- 
it was authorized "under the All Writs Act, to exercise subject matter jurisdiction over the claims presented in this case which call into question the propriety of a settlement approved in an Order of the Court." ${ }^{30}$ Judge Kent's decision was not appealed.

On more than thirty occasions since 1988, federal district and circuit courts have confronted whether to uphold removal of a state case on the basis of the All Writs Act as an independent source of removal authority. Nearly every court which has considered this question has concluded that the All Writs Act may serve as an independent basis for removal jurisdiction, ${ }^{31}$ although in a number of these cases remand

quent settlement, of the hundreds of cases brought by United States soldiers who alleged exposure to the defoliant while serving in Vietnam. This mass tort litigation is referred to as the Agent Orange Ilitigation, to distinguish it from the subsequent litigation brought about by the additional filing of claims by some of the plaintiffs after settlement of the mass tort litigation. See, e.g., Agent Orange II, 996 F.2d at 1428.

${ }^{20}$ Chance, 993 F. Supp. at 568.

${ }^{31}$ See Xiong v. Minnesota, 195 F.3d 424, 426 (8th Cir. 1999) (holding that removal is proper under the All Writs Act); Bylinski v. City of Allen Park, 169 F.3d 1001, 1003 (6th Cir.) (same), cert. denied, 119 S. Ct. 2398 (1999); NAACP, Minneapolis Branch v. Metropolitan Council, 144 F.3d 1168, 1171 (8th Cir.) [hereinafter Metropolitan Council II] (same), cert. denied, 119 S. Ct. 73 (1998); NAACP, Minneapolis Branch v. Metropolitan Council, 125 F.3d 1171, 1174 (8th Cir. 1997) [hereinafter Metropolitan Council I] (same), vacated by 118 S. Ct. 1162, and affd by Metropolitan Council II, 144 F.3d 1168 (8th Cir. 1998); In re VMS Sec. Litig., 103 F.3d 1317, 1323 (7th Cir. 1996) (same); Sable v. General Motors Corp., 90 F.3d 171, 175 (6th Cir. 1996) (same); Agent Orange II, 996 F.2d at 1431 (same); United States v. City of New York, 972 F.2d 464, 469 (2d Cir. 1992) (same); Yonkers Racing Corp. v. City of Yonkers, 858 F.2d 855, 865 (2d Cir. 1988) (same); In re Fraser, No. 598CV45, 1999 WL 1022044, at *4 (E.D. Tex. Nov. 5, 1999) (same); New York State Laborers Political Action Comm. v. Mason Tenders Dist. Council, No. 97-CV-1731, 1998 WL 146248, at *5 (N.D.N.Y. Mar. 24, 1998) (same); Lucas v. Planning Board, 7 F. Supp. 2d 310, 318-19 (S.D.N.Y. 1998) (same); Chance, 993 F. Supp. at 568 (same); Atlantic Coast Demolition \& Recycling, Inc. v. Board of Chosen Freeholders, 988 F. Supp. 486, 492 (D.N.J. 1997) (same); Harbor Venture, Inc. v. Nichols, 934 F. Supp. 322, 324 (E.D. Mo. 1996) (same); Holmes v. Trustmark Nat'l Bank, No. CIV.A. 195CV 323 GR, 1996 WL 904513, at *2 (S.D. Miss. Jan. 11, 1996) (same); Holland v. New Jersey Dep't of Corrections, Nos. 93-1683, 94-2391, 94-3087, 1994 WL 507801, at *6 (D.N.J. Sept. 14, 1994) (same); Neuman v. Goldberg, 159 B.R. 681, 685 (S.D.N.Y. 1993) (same); Ryan v. Dow Chemical Co., 781 F. Supp. 902, 918 (E.D.N.Y. 1991) (same); Ludlow Park Homeowners Ass'n v. County of Westchester, 741 F. Supp. 1126, 1130 (S.D.N.Y. 1990) (same); Nowling v. Aero Servs. Int'l., Inc., 734 F. Supp. 733, 738 (E.D. La. 1990) (same).

For cases that approved the use of, but did not actually rely on, the All Writs Act to support removal jurisdiction, see Sheet Metal Contractors Ass'n. v. Sheet Metal Workers' Int'l. Ass'n., No. 97 CIV. 6399, 1997 WL 767554 at *9 (S.D.N.Y. Dec. 11, 1997), rev'd, 157 F.3d 78 (2d Cir. 1998); Holden v. Connex-Metalna Management Consulting, No. CIV.A. 98-3326, 1999 WL 1072549 (E.D. La. Nov. 24, 1999); Mongelli v. Mongelli, 849 F. Supp. 215 (S.D.N.Y. 1994). Several courts have also considered a party's argument for removal under the All Writs Act without specifically approving nor disapprov- 
was granted after it was determined that removal was unwarranted on the particular facts of the case. ${ }^{32}$ Only three district courts ${ }^{33}$ and one

ing removal on such grounds. See Frempong-Atuahene v. Zoning Bd. of Adjustment, No. CIV.A.99-1956, 1999 WL. 1018262, at *2 n.3 (E.D. Pa. Nov. 8, 1999) (expressing no opinion on the general use of the All Writs Act as a basis for removal but finding such use "wholly unsupported by the record" in the instant case); Lloyd v. Cabell Huntington Hosp., Inc., 58 F. Supp. 2d 694, 698 (S.D. W. Va. 1999) (failing to reach the question whether the court is "empowered to permit removal of state court complaints that threaten to undermine previous orders of a federal court, but finding the question "interesting"); Webre v. Wilson, Civ. A. No. 94-3494, 1995 WL 66638, at * 1 (E.D. La. Feb. 17, 1995) (finding that " $[t]$ his case does not present the exceptional circumstances under which a district court may invoke the power of the Al! Writs Act to prevent interference with its orders").

${ }^{32}$ See Pacheco de Perez v. AT\&T Co., 139 F.3d 1368, 1378-79 (11th Cir. 1998) (holding that the facts of the case provided no exceptional circumstances to justify removal under the All Writs Act); Davis v. Glanton, 107 F.3d 1044, 1047 n.4 (3d Cir.) (noting that in "exceptional circumstances" a district court could use $\$ 1651$ "to remove an otherwise unremovable state court action" but remanding the suit because such exceptional circumstances were not demonstrated in this case), cert. denied, 522 U.S. 859 (1997); Westinghouse Elec. Corp. v. Newman \& Holtzinger, P.C., 992 F.2d 932, 937 (9th Cir. 1993) (same); First Union Nat'l. Bank v. Frempong, No. 99-1434, 1999 WL 376021, at *1 n.2 (E.D. Pa. June 9, 1999) (same); Raggio v. Omega Inst., Inc., No. 98-CV-2782, 1998 WL 377904, at *4 (D.N.J. July 2, 1998) (same); Gehm v. New York Life Ins. Co., 992 F. Supp. 209, 212 (E.D.N.Y. 1998) (same); 35 Acres Assocs. v. Adams, 962 F. Supp. 687, 692 (D.V.I. 1997) (same); Hyatt Corp. v. Stanton, 945 F. Supp. 675, 692 (S.D.N.Y. 1996) (same); Pan Atl. Group, Inc. v. Republic Ins. Co., 878 F. Supp. 630, 644 (S.D.N.Y. 1995) (same). In Selico v. Waterman Steamship Co., No. CIV A. 99-386, 1999 WL 172958, at *2 (E.D. La. Mar. 26, 1999), the defendant relied on $\S 1651$ to uphold removal, but the court postponed ruling on the motion to remand pending a ruling by the Judicial Panel on Multidistrict Litigation on whether the case would be transferred to another federal court, which would then be in a position to rule on the propriety of removal. In Lloyd v. Cabell Huntington Hosp., Inc., 58 F. Supp. $2 d 694$ (S.D. W. Va. 1999), the court remarked that the question was "an interesting one" whether the All Writs Act may be used to remove a state court case which "would threaten to undermine previous orders of a federal court," but declined to resolve it because the defendants had failed to follow the mandatory removal procedures. Id. at 698.

${ }^{33}$ See Bewley v. CIGNA Fin. Advisors, No. 97-2578 FMS, 1997 WL 601426, at *2 (N.D. Cal. Sept. 23, 1997) (stating that the "All Writs Act does not ... provide a district court with an independent source of removal jurisdiction"); Fidelity Fin. v. Robinson, 971 F. Supp. 244, 249 (S.D. Miss. 1997) (holding that the "All Writs Act is not a jurisdictional blank check" for removal, but can only be used for exceptional circumstances); In re Successor Liab. Claims Against Bairnco Corp., 837 F. Supp. 176, 177 (S.D. W. Va. 1993) (holding that "the All Writs Act is not a source of federal question jurisdiction"). In Robertson v. Western Heritage Ins. Co., No. 3:96-CV-2044-P, 1996 WL 722078 (N.D. Tex. Dec. 5, 1996), the court ruled that because no "exceptional circumstances" existed in the case, removal could not be predicated on the All Writs Act. The court did express reticence, however, about using the statute as a source of removal jurisdiction:

Finally, even if the Court believed that under the law of this circuit it could use the All Writs Act to remove this case, an issue which the Court does not 
circuit court of appeals ${ }^{34}$ by reported decisions have found that the All Writs Act is not capable of supporting removal under any circumstances. Presently, the First, Fourth, Fifth, and D.C. Circuits, as well as the Supreme Court, have not addressed the issue. ${ }^{35}$ Judge Kent in Chance called upon $\$ 1651$ (a) to perform an unusual function, but he was neither the first nor is he likely to be the last to uphold a defendant's removal of a state case on the authority of the All Writs Act. ${ }^{36}$

address, it would not choose to exercise its discretion to do so.... Further, since removal deprives the state court of an action properly before it, removal raises significant federalism concerns which caution against removal.

$1996 \mathrm{WL} 722078$, at $* 5$ (citations omitted). Additionally, in a case removed to the Eastern District of Texas, Judge Thad Heartfield in an unpublished opinion remanded the suit which had been removed on the basis, inter alia, of the All Writs Act. See Pritchett v. Albatross Tankers Corp., No. 1:98CV1509 (E.D. Tex. July 22, 1998) (holding that removal was improper for want of subject-matter jurisdiction).

${ }^{34}$ See Hillman v. Webley, 115 F.3d 1461, 1469 (10th Gir. 1997) (holding that the All Writs Act does not allow a court to acquire jurisdiction over a party otherwise not subject to its jurisdiction). Different panels of the Seventh Circuit, however, have reached disparate conclusions. Compare In re VMS Sec. Litig., 103 F.3d 1317, 1323 (7th Cir. 1996) (ruling that the All Writs Act supports removal), with In re County Collector, 96 F.3d 890, 902-03 (7th Cir. 1996) (deciding against allowing removal under the All Writs Act and indicating that, at least in a case involving a consent decree entered "without liability or 'necessity' findings," the All Writs Act is not capable of supporting removal).

${ }^{35}$ It has been argued, unsuccessfully, that the Fifth Circuit's decision in Royal Ins. Co. of Am. v. Quinn-L Capilal Corp., 960 F.2d 1286 (5th Cir. 1992), is authority for basing removal jurisdiction on the court's ancillary jurisdiction. See Robertson, $1996 \mathrm{WL}$ 722078 , at *4 n.7 (observing that "Quinn-L does not stand for the proposition that a federal court can remove a case from state court based on its ancillary jurisdiction where the state-court suit could not have been originally filed in federal court").

${ }^{36}$ Indeed, since the decision in Chance, at least six other circuit and district courts have held that removal was authorized under $\$ 1651$. See Xiong v. Minnesota, 195 F.3d 424, 426 (8th Cir. 1999) (holding that the All Writs Act could be used to support removal); Bylinski v. City of Allen Park, 169 F.3d 1001, 1003 (6th Cir. 1999) (finding that the district court correctly invoked $\S 1651$ in denying plaintiff's motion to remand to state court); Metropolitan Council II, I44 F.3d at 1171 (decided May 29, 1998) (affirming the decision in Melropolitan Council I that the district court properly exercised jurisdiction under the All Writs Act); In re Fraser, No. 598CV45, 1999 WL 1022044, at *7 (finding that the "[instant] case is the kind of extraordinary case that allows direct removal to this court under the All Writs Act"); Lucas v. Planning Bd., 7 F. Supp. 2d 310, 318 (S.D.N.Y. 1998) (decided May 19, 1998) (holding that the All Writs Act provides "an independent basis for federal jurisdiction"); New York State Laborers Political Action Comm. v. Mason Tenders Dist. Council, No. 97-CV-1731, $1998 \mathrm{WL} 146248$, at *5 (N.D.N.Y. 1998) (decided Mar. 24, 1998) (holding that the All Writs Act "provides an independent basis for finding that the PAC's complaint is subject to federal jurisdiction"). Several other post-Chance courts, although rejecting the attempt to base removal jurisdiction on $\$ 1651$ on the facts of the cases before them, have indicated that under other circumstances $\$ 1651$ could support removal to federal court. See, e.g., Pacheco de Perez v. AT\&T Co., 139 F.3d 1368, 1378 (11th Cir. 1998) (recognizing that 
In this Part, I examine some of these cases in which $\S 1651$ (a) has been allowed as removal authority. An examination of this area reveals that there are predominately two distinct but related strains of cases in which courts have relied on the All Writs Act to approve a defendant's removal of a state case:

Type I. A subsequently filed state court suit threatens to interfere with a prior federal judgment; or

Type II. A prior federal judgment has preclusive effect on subsequently filed state court claims.

Some cases, of course, may fall within both types. For example, in Type II cases, the subsequent suit is often also considered a threat to the prior federal judgment. In contrast, most Type I cases are distinctly in that grouping only. Nevertheless, under either category, concern about the impact of a subsequent state proceeding clearly influences courts' judicial exercise of the All Writs Act to uphold removal of the cases.

Categorizing cases into types provides two benefits beyond serving as a cataloguing technique. First, identifying the nature of the case highlights an essential difference between Type I and Type II. In pure Type I cases (in which the threat to a prior federal judgment is at stake, but that judgment does not have a preclusive effect on the subsequent litigation) the defendant is unable to obtain early disposition of the case in the state forum by filing a defensive plea and motion to dismiss. This is a central distinction to grasp between Type I and Type II cases because, as I argue in Part IV, the Supreme Court's recent decision in Rivet $v$. Regions Bank $^{37}$ should be read as foreclosing $\$ 1651$ (a) as removal authority for most Type II cases, as well as for a small number of Type I cases.

The second benefit of the classification system is that it helps lead to a clearer understanding of why federal intervention is appropriate

under exceptional circumstances, the All Writs Act may justify removal); First Union Nat'l. Bank v. Frempong, No. 99-1434, 1999 WL 376021, at *1 n.2 (E.D. Pa. June 9, 1999) (noting that defendants "failed to present any exceptional circumstances that would justify removal" under the All Writs Act); Gehm v. New York Life Ins. Co., 992 F. Supp. 209, 212 (E.D.N.Y. 1998) (acknowledging that removal under the All Writs Act is appropriate "to preserve and effectuate orders previously issued" by a district court); Raggio v. Omega Inst., Inc., No. 98-CV-2782, 1998 WL 377904, at *4 (D.N.J. July 2, 1998) (holding that the All Writs Act does not justify removal because "[d] efendants point to no possible scenarios in which the new state court action would interfere with any of this Court's previously issued orders").

${ }^{\text {s7 }} 522$ U.S. 470 (1998). 
in some cases and not in others. As discussed more fully in Part IV, my argument against extending removal jurisdiction to the All Writs Act should not be confused with the notion that federal intervention to protect and effectuate federal judgments is never warranted. To the contrary, although reliance on the All Writs Act to support removal may be inappropriate, intervention by a federal court through issuance of injunctive relief is, and should continue to be, an effective means of protecting prior federal decrees in certain instances. This classification system may help suggest ways to reconcile the underlying tension which emerges whenever a federal court is asked to intervene in state proceedings: that is, how to honor the important principles of federalism and comity, which counsel deference to state courts, without sacrificing or compromising the enforcement and effectuation of prior federal judgments.

\section{A. The Second Circuit's Decision in Yonkers: The First Case}

From 1789 to 1987 , no court had ever ruled by reported decision that the All Writs Act could serve as an independent basis for removal. Then, in 1988, in Yonkers Racing Corp. v. City of Yonkers, the Second Circuit placed its imprimatur on this unconventional use of $\$ 1651(\mathrm{a}) .^{33}$ In the underlying litigation in Yonkers, the City of Yonkers had been found liable for causing the "extreme concentration of subsidized housing" through a practice of selecting or supporting "only sites that would preserve existing patterns of racial segregation.",39 The district court ordered the city to remedy the constitutional violations. The City of Yonkers balked and found itself at risk of being held in contempt of court for its failure to comply with the district court's directive. Consequently, the city was forced to enter into a consent decree whereby it agreed to "designat [e] 7 sites on which to build a total of 200 units of public housing" and to commence eminent domain proceedings, if necessary, to acquire these sites. ${ }^{40}$ After condemnation proceedings on several properties had been initiated, the soon-to-bedispossessed landowners filed separate suits in state court alleging that the city had failed to comply with proper condemnation procedures and seeking, inter alia, injunctive relief to prevent the city from ac-

ss 858 F.2d 855 (2d Cir. 1988).

${ }^{39} \mathrm{Id}$. at 859 (quoting United States v. Yonkers Bd. of Educ., 837 F.2d 1181, 1194 (2d Cir. 1987)).

${ }^{40} \mathrm{Id}$. 
quiring the sites. ${ }^{41}$ The district court ordered the state court actions removed to federal court. ${ }^{42}$

The Second Circuit upheld removal of the state cases, observing that "the district court was confronted both with the need to vindicate the constitutional rights of those in Yonkers who have been denied fair housing and the very real possibility that the City of Yonkers would be subjected to inconsistent orders from the state court and the federal court." ${ }^{, 3}$ Drawing on language from the Supreme Court's decision in United States v. New York Telephone Co., ${ }^{44}$ the Second Circuit in Yonkers restated the principle that the All Writs Act "authorizes a federal court in exceptional circumstances to issue such orders to persons 'who, though not parties to the original action or engaged in wrongdoing, are in a position to frustrate the implementation of a court order or the proper administration of justice." ${ }^{, 15}$ The Second Circuit then determined that "exceptional circumstances" existed in the case. ${ }^{46}$ The court particularly doubted whether the City of Yonkers, "a reluctant condemnor, which at every opportunity has resisted implementation of the Housing Remedy Order, could be counted on in state court to adequately protect the integrity of the Consent Decree. ${ }^{\text {p77 }}$ The court narrowly ruled, therefore, that the All Writs Act supported removal of this civil rights case "in order to vindicate the constitutional rights of existing parties. ${ }^{48}$

Parsing the rationale of the court's decision, Yonkers is readily identifiable as a pure Type I case. The state proceedings brought subsequent to the federal action threatened the continued vitality of the federal order. ${ }^{49}$ Yonkers should not be classified as a Type II case. The prior consent decree adopted and approved by the federal court could not be used to support a claim preclusion defense to the claims asserted by the landowners seeking to avert a condemnation decree.

11 See id. at 860 (discussing the background of the case). This state suit was brought pursuant to Article 78 of the New York Civil Practice Law and Rules. See id. at 858 (reviewing the procedural background of case).

${ }^{12}$ See id.

${ }^{43}$ Id. at 863.

14434 U.S. 159 (1977).

15 Yonkers, 858 F.2d at 863 (emphasis added) (quoting Benjamin v. Malcolm, 803 F.2d 46, 53 (2d Cir. 1986)).

${ }^{46} I d$. at 865 .

${ }^{17}$ Id.

43 Id. at 864 .

49 See id. at 865 (holding that "removal was proper under the All Writs Act... to protect the integrity of the Consent Decree"). 
The federal consent decree directed that steps be taken to eradicate racially discriminatory practices, but no specific ruling by the court could be cited as res judicata to extinguish the landowners' state law claims.

Yonkers's reliance on the excerpted language from the Supreme Court's decision in New York Telephone presaged similar reliance by nearly all courts that have subsequently approved removal pursuant to the All Writs Act. ${ }^{50}$ In New York Telephone, the Federal Bureau of Investigation obtained an order authorizing the installation of pen registers on two telephone lines. ${ }^{51}$ The pen registers enabled the FBI to record numbers dialed by the telephone users by capturing the electronic signals that were emitted when the phones were used. ${ }^{52}$ In order to install the devices without being detected, the FBI required the assistance of the phone company. The phone company moved to vacate portions of the order, and the district court concluded that it had jurisdiction pursuant to the All Writs Act and pursuant to its inherent power to effectuate its order compelling the phone company's assistance. ${ }^{53}$ On appeal, the Supreme Court affirmed the district court's order based on the authority of the All Writs Act. ${ }^{54}$ There were two points central to the Court's decision. First, the Supreme Court found that a district court may invoke the All Writs Act "as may be necessary or appropriate to effectuate and prevent the frustration of orders it has previously issued in its exercise of jurisdiction otherwise obtained. ${ }^{n 5}$ Thus, a prerequisite to invocation of the All Writs Act is that the jurisdiction of the district court must already be established on some independent ground, as it was in New York Telephone. ${ }^{56}$ The second essential part of the Court's ruling was its finding that "without the [phone] Company's assistance there is no conceivable way in

${ }^{50}$ See, e.g., In re VMS Sec. Litig., 103 F.3d 1317, 1323 (7th Cir. 1996) (citing New Yonk Telephome to support upholding a district court's removal of potentially conflicting concurrent state court actions); Sable v. General Motors Corp., 90 F.3d 171, 175 (6th Cir. 1996) (same); Agent Orange II, 996 F.2d 1425, 1431 (2d Cir. 1993) (same).

51 434 U.S. 159, 161-63 (1977).

${ }^{32}$ See id. at $161 \mathrm{n} .1$ (describing the function of a pen register). The pen register enabled the FBI to record the numbers dialed from a phone, not to overhear what was said or, for that matter, "whether calls [were] actually completed." Id.

${ }^{33}$ See id. at 163 (discussing the procedural history of the case).

${ }^{54}$ See id. at 172-78 (discussing the All Writs Act and reversing the judgment of the court of appeals).

55. Id. at 172 (emphasis added).

${ }^{36}$ See id. at 169-70 (finding the requisite jurisdiction to issue the order for the pen register installation in Federal Rule of Criminal Procedure 41(b)). 
which the surveillance authorized by the District Court could have been successfully accomplished. ${ }^{57}$ Neither of these two findings, critical to the Court's holding in New York Telephone, is discussed in Yonkers's approval of using the All Writs Act as a removal basis. On close examination, removal of the state cases by the All Writs Act failed to satisfy either requirement established by the Supreme Court in New York Telephone. Regarding the first-that the court must be acting "in its exercise of jurisdiction otherwise obtained" Circuit never identified the source of its jurisdiction over the removed cases. Since no other independent basis for obtaining jurisdiction existed, the first requirement from New York Telephone appears unsatisfied. Secondly, the circuit court's stated preference for removal over injunctive relief cannot be squared with the requirement in New York Telephone that there be no other conceivable recourse available to effectuate the district court's order. Enjoining the state court proceedings may have been an available option for the federal court to protect its prior judgment; removal was not.

Yonkers thus broke new ground in approving use of the All Writs Act as a source of removal authority. Although the Second Circuit sought to confine its holding by approving use of $\S 1651$ (a) only in cases involving "exceptional circumstances," the tight universe of "exceptional circumstances" established by Yonkers would soon expand. The narrow holding in the Yonkers civil rights case was quickly enlarged by other lawyers who advocated use of the All Writs Act for their clients in non-civil rights cases. ${ }^{59}$ The "exceptional circumstances" found by the Second Circuit to have existed in Yonkers by virtue of the need to vindicate constitutional rights also have been found in a number of other situations, where it was not racial discrimination and lofty constitutional principles at stake, but instead, the rights of corporate defendants in commercial disputes. Read in historical context, when the Second Circuit in Yonkers approved use of the All Writs Act to support removal, it was as though a power that had lain dor-

${ }^{57}$ Id. at 175 . As Congress had previously authorized federal courts to issue orders directing telephone companies to assist in installing electronic wiretaps, the Court observed that "it would be remarkable if Congress thought it beyond the power of the federal courts to exercise, where required, a discretionary authority to order telephone companies to assist in the installation and operation of pen registers, which accomplish a far lesser invasion of privacy." Id. at 177.

${ }^{38} I d$. at 172.

${ }^{59}$ See supra notes 31-32 (listing numerous cases invoking the All Writs Act, often in non-civil rights contexts). 
mant for nearly two hundred years was suddenly awakened. Once awakened, that force would not be silenced.

\section{B. Agent Orange II and the Expanded Use of § 1651(a) to Support Removal}

Not long after the decision in Yonkers, the Second Circuit again found itself confronted with a threat to the continued sanctity of a prior federal judgment. Again, the Second Circuit approved use of the extraordinary writ to support removal of offending state court litigation. In Agent Orange II, the Second Circuit approved a district court's use of the All Writs Act to remove two state class action suits in which the state plaintiffs attempted to assert claims identical to those consolidated years earlier and extinguished by a federal court. ${ }^{60}$ The federal district court overseeing the consolidated cases had approved a global settlement that specifically extinguished the claims of all present and future claims of class members, including all class members "who have not yet manifested injury." ${ }^{\text {61 }}$ The plaintiffs asserted in their state court suit that they could not have been part of the federal class because they had not yet manifested injury. ${ }^{62}$ Although cautioning that "the All Writs Act is not a jurisdictional blank check which district courts may use whenever they deem it advisable," the Second Circuit upheld the district court's removal order, citing New York Telephone and finding that "exceptional circumstances" existed to justify removal. ${ }^{63}$ According to the Second Circuit, the district court "was enforcing an explicit, ongoing order against relitigation of matters it already had decided. ${ }^{n 64}$ The court determined that plaintiffs' state court class action suits directly threatened a prior federal order, stating: "If Agent Orange victims were allowed to maintain separate actions in state court, the deleterious effect on the Agent Orange I settlement mechanism would be substantial. The parties to the settlement implicitly recognized this when they agreed that all future suits by class members would be permanently barred.. ${ }^{65}$ Moreover, because the prior federal judgment had extinguished all such claims, that judg-

${ }^{\infty} 996$ F.2d 1425, 1430 (2d Cir. 1993).

${ }^{61}$ Id. at 1429.

62 See id. at 1434 (noting and addressing the plaintiffs' argument that they had not yet manifested injury).

${ }^{63}$ Id. at 1431.

${ }^{61}$ Id.

${ }^{65}$ Id. 
ment had a "preclusive effect" ${ }^{\text {"166 }}$ on plaintiffs' state court claims:

It is difficult to conceive of any state court properly addressing a victim's tort claim without first deciding the scope of the Agent Orange I class action and settlement. The court best situated to make this determination is the court that approved the settlement and entered the judgment enforcing it.

Here then is a case which falls into both Types I and II. It is a Type I case in that if the plaintiffs were permitted to maintain their subsequent suits in state court, the judgment of the federal court approving the mass settlement would be directly challenged. ${ }^{68}$ It is also a Type II case in that the claims the plaintiffs sought to bring in state court had previously been extinguished by the federal court. ${ }^{69}$ The Second Circuit explicitly recognized that both concerns were at stake in the litigation. ${ }^{70}$

Interestingly, the Second Circuit rejected a second basis for jurisdiction cited by the district court. In addition to $\S 1651$ (a), the district court had also justified removal on the artful pleading doctrine, ${ }^{71}$ relying principally on the Supreme Court's decision in Federated Department Stores, Inc. v. Moitie. ${ }^{72}$ In Moitie, several price-fixing cases had been consolidated in federal court and subsequently dismissed. ${ }^{73}$ While most of the plaintiffs filed direct appeals, two of the plaintiffs chose instead to file separate claims in state court. The Supreme Court upheld the removal of the state actions, noting in footnote two that "at least some of the claims had a sufficient federal character to support removal. ${ }^{74}$ The Supreme Court has subsequently recognized that this footnote in Moitie "has caused considerable confusion" be-

${ }^{66} I d$.

${ }^{67} \mathrm{Id}$.

68 Describing the parameters of the statute, the court observed, "A district court, in exceptional circumstances, may use its All Writs authority to remove an otherwise unremovable state court case in order to "effectuate and prevent the frustration of orders it has previously issued in its exercise of jurisdiction otherwise obtained." Id. (quoting United States v. New York Tel. Co., 434 U.S. 159, 172 (1977)).

${ }^{69}$ See id. (discussing the "preclusive effect" of the prior judgment).

${ }^{70}$ See $i d$. (noting that " $[t]$ he district court was not determining simply the preclusive effect of a prior final judgment on claims or issues expected to be raised in subsequent collateral proceedings; it was enforcing an explicit, ongoing order against relitigation of matters it already had decided").

"See id. (discussing the rationale of the district court).

72452 U.S. 394 (1981).

${ }^{73}$ See id. at 395-97 (discussing the procedural history of the case).

${ }^{74}$ Id. at 397 n.2. 
cause it suggests that a federal claim preclusion defense might serve as a basis for removal. ${ }^{75}$ Typical of this confusion is the decision by the district court in Agent Orange II to rely on Moitie's "enigmatic" footnote as one basis for removal. ${ }^{77}$ The Second Circuit disagreed with the district court on this point, remarking that in order to be removable under Moitie, the state claim must be virtually identical to a prior federal claim "expressly grounded on federal law." ${ }^{78}$ Because the prior federal claims in the massive Agent Orange litigation were tort claims that were in federal court by virtue of diversity jurisdiction, the Second Circuit found that the artful pleading doctrine, as discussed in Moitie and other cases, did not support removal of the subsequently-filed state claims. ${ }^{79}$

Such strained interpretations of Moitie and the confusion engendered by these unwieldy holdings should-thankfully-no longer complicate the case law in this area, following the Court's recent decision in Rivet $v$. Regions Bank. ${ }^{80}$ Rivet concerned the power of a federal bankruptcy court to remove a case from Louisiana state court on the ground that the plaintiff's state cause of action was completely precluded by the bankruptcy court's prior judgment on a federal question. ${ }^{81}$ The Fifth Circuit approved the district court's denial of the plaintiff's motion to remand, relying on an earlier Fifth Circuit precedent $^{82}$ that construed Moitie as dictating that a defendant could remove a case "where a plaintiff files a state cause of action completely precluded by a prior federal judgment on a question of federal law.", The Moitie footnote had long caused confusion, but numerous courts, including the Fifth Circuit, had held that under Moitie a federal question could exist to support removal as an exception to the wellpleaded complaint rule. The Supreme Court reversed the Fifth Cir-

${ }^{75}$ Rivet v. Regions Bank, 522 U.S. 470, 478 (1998).

${ }^{76}$ Rivet v. Regions Bank, 108 F.3d 576, 584 (5th Cir. 1997), rev'd, 522 U.S. 470 (1998).

7 See Agent Orange II, 996 F.2d at 1431 (discussing the district court's reliance on the Moitie footnote).

${ }^{7 \mathrm{~B}}$ Id. (quoting Travelers Indem. Co. v. Sarkisian, 794 F.2d 754, 760 (2d Cir. 1986)).

${ }^{79}$ See id. (declining to base removal on Moitie's artful pleading doctrine, as interpreted by Travelers).

${ }^{80} 522$ U.S. 470 (1998).

${ }^{81}$ See id. at $472-74$ (discussing the history of the case).

82 See Carpenter v. Wichita Falls Indep. Sch. Dist., 44 F.3d 362, 370 (5th Cir. 1995) (interpreting Moitie as allowing removal where a state action is completely precluded by a federal decision on federal law).

${ }^{83}$ Rivel, 108 F.3d at 586 (quoting Carpenter, 44 F.3d at 370). 
cuit, clarifying that "Moitie did not create a preclusion exception to the rule, fundamental under currently governing legislation, that a defendant cannot remove on the basis of a federal defense." ${ }^{84}$ Thus, if the holding in Rivet were applied retroactively to Agent Orange II, then the fact that the claims in the consolidated mass tort Agent Orange litigation were merely state law claims in federal court only on diversity grounds would be considered irrelevant to whether Moitie was a valid basis for removal. As the Court observed in Rivet, "claim preclusion by reason of a prior federal judgment is a defensive plea that provides no basis for removal under $\S 1441$ (b). ${ }^{35}$ Removal jurisdiction, according to Rivet, never exists by virtue of claim preclusion, regardless of whether the federal court previously rendered its decision in a federal question or diversity case. ${ }^{86}$ The Supreme Court further clarified in Rivet that the proper forum to raise a preclusion defense is in the state court. ${ }^{87}$ The state court judgment is then ultimately subject to review by the Supreme Court. ${ }^{88}$

Following Rivet's clarification of Moitie, we may ask how this decision affects the use of $\$ 1651$ (a) to uphold a defendant's removal of a state case. How can removal be on sounder footing pursuant to $\S 1651$ (a) when the underlying basis for removal is the allegation that the prior federal judgment extinguishes the state claims? After Rivet, a compelling argument can be made that exercise of $\S 1651$ (a) in most Type II cases is no longer supportable. If a subsequent state case involves the same claims which a federal court previously adjudicated, then the proper course is either to bring a defensive plea in the state

${ }^{84}$ Rivel, 522 U.S. at 478 . The fundamental jurisdictional maxim, derived from the "well-pleaded complaint rule," requires the federal question appear on the face of a well-pleaded complaint. See Louisville \& Nashville R.R. v. Mottley, 211 U.S. 149, 152 (1908) (describing the well-pleaded complaint rule). The rule, which does not permit federal court review of federal issues where only a federal defense-as opposed to a federal claim-has been raised, has been staunchly criticized. See GHARIES AlAN WRIGHT, LAW OF FEDERAL COURTS § 18, at 109 (5th ed. 1994) ("If the basis for original federal-question jurisdiction is that the federal courts have a special expertness in applying federal law ... it would seem that the courts should have jurisdiction where there is some federal issue regardless of which pleading raises it."); Donald L. Doernberg, There's No Reason for It; It's Just Our Policy: Why the Well-Pleaded Complaint Rule'Sabotages the Purposes of Federal Question Jurisdiction, 38 HASTINGs L.J. 597, 599 (1987) (arguing that the well-pleaded complaint rule ought to be abandoned).

${ }_{85}$ Rivet, 522 U.S. at 478.

${ }^{86}$ See id. (clarifying that claim preclusion provides no basis for removal).

${ }^{87}$ See id. (stating that the state proceedings are appropriate for such a defense).

${ }^{83}$ See id. (explaining that the Supreme Court can review the state court's judgment on the preclusion defense). 
court that the federal judgment precludes the subsequent state claims, or for the federal court to enjoin further state court proceedings. Removal under either Moitie claim preclusion, the All Writs Act, or any other basis which is grounded in the preclusive effect of a prior federal judgment, should not be sustainable. To permit removal under these circumstances would render the rationale in Rivet meaningless.

The Eighth Circuit, however, has read Rivet differently. That circuit has ruled recently that Rivet does not preclude removal on the basis of the All Writs Act. In Metropolitan Council II, a plaintiff class consisting of all Minneapolis public school students was certified in state court $^{89}$ The students asserted violations of state and federal law against numerous Minneapolis defendants. ${ }^{90}$ More than six months earlier, the Metropolitan Council, one of the defendants in the case, had entered into a consent decree which resolved a federal Fair Housing Act class action suit. ${ }^{91}$ Under the terms of the consent decree, the Metropolitan Council had agreed to alter racially-discriminatory housing practices. It is noteworthy that some members of the plaintiff class in the federal suit were also plaintiffs in the state class action. ${ }^{92}$

The Metropolitan Council removed the state suit to federal court, asserting that the claims made against them in the state action were identical to the claims previously made against them in the federal action, which were settled by the consent decree. The district court denied remand as to the Metropolitan Council on two specific grounds: jurisdiction was held to have been established first, under the All Writs Act, and second, under the Moitie federal claim preclusion jurisdiction doctrine. ${ }^{93}$ The Eighth Circuit upheld the denial of remand, finding that the All Writs Act could serve as an independent basis for removal jurisdiction. ${ }^{94}$ The circuit court did not reach the issue of whether

${ }^{89} 144$ F.3d 1168 (8th Cir.), cert. denied, 119 S. Ct. 73 (1998).

90 See id. at 1171 ("NAACP started out as a state-law-based class action brought against numerous defendants in Minnesota state court.").

${ }^{91}$ See id. ("Just six months earlier the Met Council had bound itself... under a federal consent decree.").

${ }^{92}$ See id. ("The Hollman decree concluded an earlier Fair Housing Act lawsuit brought by the NAACP and a class some of whose members also belonged to the student class.").

${ }_{93}$ See id. (recognizing that the district court based its jurisdiction on the All Writs Act and Moitie's claim preclusion doctrine).

${ }^{9}$ See Metropolitan Council 1, 125 F.3d 1171, 1173 (8th Cir. 1997) (holding that the All Writs Act can be utilized to authorize removal from state court to protect the integrity of a federal consent decree). Two years after its decision in Metropolitan Council I, in a separate but related action, the Eighth Circuit reaffirmed that the All Writs Act 
Moitie jurisdiction existed. ${ }^{95}$ The Eighth Circuit then dismissed the plaintiffs' claims against the Metropolitan Council as precluded by the prior consent decree. ${ }^{96}$ The plaintiffs then sought certiorari from the Supreme Court.

While that appeal was pending, the Court decided Rivet. Thereafter, the Court granted certiorari in Metropolitan Council I for the limited purpose of vacating the Eighth Circuit's decision and remanding the case to the circuit court for reconsideration in light of the ruling in Rivet. ${ }^{97}$ The Rivet case did not involve the All Writs Act, only whether Moitie federal claim preclusion was a proper basis for removal. ${ }^{98}$ Therefore, at the very least, by vacating and remanding the Eighth Circuit's decision, the Court indicated that the issues in the two cases were interrelated. On remand, however, the Eighth Circuit reaffirmed its prior holding, noting that the basis of its original decision to uphold removal was the All Writs Act and that it had expressly not reached the question of whether Moitie provided a separate basis for removal. ${ }^{99}$

There can be little doubt from reading the Eighth Circuit's opinion that the preclusive effect of the prior federal judgment was the primary justification for removing the case, even if $\S 1651$ (a) was the technical basis for removal. Resort to the All Writs Act was approved precisely because the state court action contained identical claims to those brought and settled in the federal suit. As the Eighth Circuit

could be used to authorize removal. See Xiong v. Minnesota, 195 F.3d 424 (8th Cir. 1999). In Xiong, the Eighth Circuit chastened the district court for deciding that removal was improper under the All Writs Act when "we had already answered the question affirmatively in [Metropolitan Council I] and [Metropolitan Council II]." Id. at 426.

${ }^{95}$ See id. at 1174 (focusing exclusively on an analysis of the All Writs Act as an independent basis for removal jurisdiction and choosing not to decide whether removal was appropriate under the artful pleading doctrine).

${ }^{96} I d$ at 1175 (finding that the student class was in privity with the earlier class).

${ }^{97}$ NAACP v. Metropolitan Council, 522 U.S. 1145 (1998) (vacating the judgment and remanding the case to the United States Court of Appeals for the Eighth Circuit).

${ }^{93}$ There is certainly no discussion of the All Writs Act as a source of removal authority in any of the briefs filed by the parties. See, e.g., Reply Brief for Petitioners, Rivet v. Regions Bank, 118 S. Ct. 921 (1998) (attacking respondent's construction of the Moitie footnote without reference to the All Writs Act), available in 1998 WL 4677; Respondents' Brief on the Merits, Rivet v. Regions Bank, 118 S. Ct. 921 (1998) (basing an argument on claim preclusion without reference to the All Writs Act), available in 1997 WL 769468.

9o See Metropolitan Council II, 144 F.3d 1168, 1169 (8th Cir. 1998) ("WW]e upheld the district court's decision to take jurisdiction of the state-law claims in NAACP based on the All Writs Act, not on Moitie or claim preclusion ...."). 
observed in its first opinion:

In this suit, the NAACP and the student class seek state injunctive relief against the Met Council concerning the very matters the Hollman [federal] decree governs. Although this class action is not removable under the federal removal statutes, the district court was confronted with a situation where parties subject to the district court's continuing jurisdiction ... were resorting to a state forum to relitigate settled and released claims. Faced with this circumstance, we believe the district court was warranted in authorizing removal from state court under the All Writs Act.... 100

One would have thought that after Rivet, it would have been clear that removal is not permissible based on federal claim preclusion, regardless of the procedural mechanism invoked.

Although a case may be removed because it has been completely preempted by a federal statute, "[a] case blocked by the claim preclusive effect of a prior federal judgment differs from the standard case governed by a completely preemptive federal statute in this critical respect: The prior federal judgment does not transform the plaintiff's state-law claims into federal claims but rather extinguishes them altogether. ${ }^{n 101}$ For this reason, the Court reasoned that a preclusion defense should be treated no differently under the well-pleaded complaint rule than any other defensive plea "and is therefore not a proper basis for removal." ${ }^{102}$ The preclusion defense is then "properly made in the state proceedings, and the state courts' disposition of it is subject to this Court's ultimate review." ${ }^{103}$ Since the underlying basis for removal articulated by the Eighth Circuit in Metropolitan Council I was that the "student class seek state injunctive relief against the Met Council concerning the very matters the Hollman [federal] decree governs" and the state plaintiffs "were resorting to a state forum to relitigate settled and released claims," the holding in Rivet should have led the circuit court to treat the preclusive effect of the federal consent decree merely as a defensive plea to be brought before and resolved by the state court judge, not as a basis for removal under the All Writs Act or any other procedural device. Alternatively, the district court may have been able to enjoin fur-

\footnotetext{
${ }^{100}$ Metropolitan Council I, 125 F.3d at 1173.

${ }^{101}$ Rivet v. Regions Bank of Louisiana, 522 U.S. 470, 476 (1998).

102 Id. at 477.

103 Id. at 478.

${ }^{104}$ Metropolitan Council I, 125 F.3d at 1173.
} 
ther state court proceedings, had the Metropolitan Council sought such relief and assuming that the injunction did not run afoul of the Anti-Injunction Act.

\section{Removal Under § 1651(a) by Other District and Circuit Courts}

There have been a few courts which have declined to approve removal under the All Writs Act. Hillman v. Webley, decided by the Tenth Circuit, represents the only circuit court of appeals decision which has refused to permit removal pursuant to $\S 1651(a) .^{105}$ In Hillman, a federal district court in Colorado utilized the All Writs Act to uphold a defendant's removal of a state court action filed in California. A series of lawsuits filed in various federal districts previously had been consolidated in the United States District Court for the District of Colorado. ${ }^{106}$ After this multidistrict action was settled, a separate action was filed in California state court by one of the class members in the multidistrict litigation against an individual who had not been a part of the multidistrict litigation in Colorado. This defendant asserted cross-claims in the California state action against several parties who had been defendants in Colorado. ${ }^{107}$ The entire action, including the cross-claims, was removed to the Colorado federal district court, purportedly by relying on the All Writs Act. Diversity of citizenship had existed in the state case but because the "statutory time for removal expired, ${ }^{n 108}$ the All Writs Act was invoked as a residual source of removal authority.

The Tenth Circuit held, however, that the action was not removable pursuant to the All Writs Act. The Tenth Circuit discussed precedents from other jurisdictions which approved the use of the statute as a source of removal authority, but ultimately decided to follow its own earlier decision in which it held that the All Writs Act "does not allow a court to 'acquire jurisdiction over an individual or property not otherwise subject to its jurisdiction' and 'does not operate to confer jurisdiction." ${ }^{109}$ Without an independent basis for sub-

105115 F.3d 1461 (10th Cir. 1997).

${ }^{106}$ See id. at 1463 ("The cases were eventually consolidated for pretrial purposes on April 9, 1992, pursuant to an order of the Judicial Panel on Multidistrict Litigation, in the United States District Court for the District of Colorado, under 28 U.S.C. § 1407.").

${ }^{107}$ See id. at 1464 (detailing the defendant's motion to set aside the agreement and to file cross-claims).

${ }^{103}$ Id. at 1469 n.6.

${ }^{109}$ Id. at 1469 (citing Commercial Sec. Bank v. Walker Bank \& Trust Co., 456 F.2d 
ject matter jurisdiction, the Tenth Circuit reasoned that the All Writs Act could not be used to remove an otherwise unremovable case. Interestingly, the court in Hillman also recognized a second error in the attempted removal of the California state action to the United States District Court for the District of Colorado. The court correctly noted that under $\$ 1441$ (a), proper removal would not have been to Colorado anyway but "would have been to federal district court in California." ${ }^{\text {"10 }}$ We will see later, in Part III, that one argument which has been made by $\S 1651$ (a) removal advocates is that the original jurisdiction possessed by a court in issuing its prior order can satisfy the subject matter jurisdiction requirements for a case removed pursuant to $\S 1651$ (a). ${ }^{111}$ As I argue below, however, because the All Writs Act contains no internal venue provision comparable to $\S 1441$ (a), even if the jurisdiction originally possessed by a court could be a valid source of subject matter jurisdiction for a case removed under the All Writs Act, only the court which issued the prior judgment would have jurisdiction to remove a subsequent state case under $\S 1651$ (a). ${ }^{12}$ Thus, even if this enabling contention were accepted, a defendant would not be able to remove a state case if it were filed in a district other than the one in which the federal judgment was entered.

Only two federal district courts in reported decisions have expressly found that removal is not independently authorized under the All Writs Act. ${ }^{113}$ If recent history is any guide, Hillman and these district court decisions appear destined to be relegated to minority status; every other court which has considered removal under the All Writs Act has approved the practice, ${ }^{114}$ although several have narrowly declined to permit removal because "exceptional circumstances" were

1352, 1355 (10th Gir. 1972)).

${ }^{110} I d$ at 1470 n.6.

${ }^{11}$ See infra text accompanying notes 170-78 (analyzing whether removal jurisdiction may be based on a court's original jurisdiction to enforce its original judgment).

${ }^{112}$ See infra text accompanying notes 179-82 (arguing that, based on current statutes, ancillary removal jurisdiction is a theory of limited practical application for justifying removal authority under the All Writs Act).

${ }^{119}$ See Fidelity Fin. v. Robinson, 971 F. Supp. 244 (S.D. Miss. 1997) (holding that "the exercise of All Writs removal jurisdiction" is not a "jurisdictional blank check"); In $r e$ Successor Liab. Claims Against Bairnco Corp., 837 F. Supp. 176 (S.D. W. Va. 1993) (holding that the All Writs Act is not a source of federal question jurisdiction).

${ }^{111}$ See supra note 31 (citing authority that demonstrates that nearly every court which has considered this question has concluded that the All Writs Act may serve as an independent basis for removal jurisdiction). 
not found to exist. ${ }^{115}$

Following Agent Orange II, and serving as another example of a Type II case, is the Seventh Circuit's decision in In re VMS Securities Litigation. ${ }^{116}$ In VMS Securities, a group of California investors who previously elected not to opt-out of two related federal class actions attempted to bring another class action lawsuit against the same defendant in state court after the federal class actions had been settled. ${ }^{117}$ The plaintiffs had had a right to opt-out of the class but chose not to do so. The court upheld the removal of the state class action suit under the All Writs Act. ${ }^{118}$ The settlements approved by the federal district courts had provided that the plaintiffs released "every asserted or potential" claim under "federal, state or common law." "119

Likewise, the Seventh Circuit upheld the removal of the state class action suit to federal court. Central to the circuit court's decision was that the California investors were members of the federal class actions and had chosen to participate in those class settlements. As a result, they were subsequently barred from asserting their state court claims:

115 See supra note 32 (citing cases in which removal was denied after it was determined that removal was unwarranted on the particular facts of the case).

${ }^{116} 103$ F.3d 1317 (7th Cir. 1996).

117 The plaintiffs' claim was that "shortly after consolidation of the first federal class action in Illinois, Prudential developed a scheme to minimize their overall litigation liability; this scheme entailed Prudential fraudulently inducing investors to join in the class settlements." Id. at 1321. In framing their argument in this fashion, the plaintiffs hoped to avoid the preclusive effect of the prior federal judgment, maintaining that they would have opted-out of the federal class but for Prudential's fraudulent inducements. Furthermore, the plaintiffs claimed that their state actions were based on Prudential's post-settlement conduct, meaning the actions taken after the class had been certified and notices had been mailed out. Id. at 1322. In this way, the plaintiffs hoped to convince the court that the release language in the settlement agreements could not bar their claims because those claims did not arise, according to the plaintiffs, until after the releases had been signed. See id. (explaining plaintiffs' argument that their claims were "based on Prudential's ... conduct after the district judges had certified the class actions, approved the class settlements, and mailed out the class notices"). The court declined to accept the plaintiffs' argument, however, and found that their claims were barred. "What the California Investors characterize as "nonreleased' fraudulent misrepresentation and breach of fiduciary duty claims are nothing more than objections to Prudential's conduct during the class notice/opt-out period." Id. The court further noted that "these claims arose out of the settlement agreement process, in which the district court had expressly retained exclusive jurisdiction." Id at 1322 n.1.

${ }^{118}$ See id. at 1321 ("This circuit firmly recognizes the power of a district court to retain jurisdiction over a settlement agreement to protect and enforce its own judgments.").

${ }^{119} I d$ at 1319. 
The California Investors could easily have opted out of the settlement agreements in order to preserve their California claims. "By electing not to opt out of the class," the California Investors "received the benefits and accepted the detriments of the settlement." As such, their failure to opt out manifested their consent to have the district court resolve matters involving the class action settlements.

Consequently, "[d]efenses to the preclusive effects of the settlement ... must be presented to the district court. ${ }^{\text {n121 }}$ Interestingly, the defendant did not seek relief before the state court by filing an affirmative defense of res judicata or claim preclusion; indeed, the alternative option of seeking relief before the state tribunal was not discussed by the Seventh Circuit in its decision. To the contrary, the court apparently believed that this was not a sufficient alternative remedy as it opined that the only "appropriate place for the California Investors to address their concerns about Prudential's alleged fraud and misrepresentation in the settlement process" was in the district court. ${ }^{122}$ According to the Seventh Circuit, the state claims "clearly attempted an 'end run' around the class action settlements and thus should be treated as 'disguised estoppel' claims." ${ }^{123}$ Citing the same language from the Supreme Court's decision in New York Telephone upon which both Yonkers and Agent Orange II relied, the Seventh Circuit emphasized that the Supreme Court has "championed a federal court's power to use the [All Writs] Act in order 'to effectuate and prevent the frustration of orders it has previously issued in its exercise of jurisdiction otherwise obtained.' $" 124$

Even as it broadened the scope of removal jurisdiction by invoking $\S 1651$ (a), the Seventh Circuit also advised that this was an "exceptional" case, narrowly warranted on the facts before the court, just as the courts in Yonkers and Agent Orange II similarly observed. ${ }^{125}$ It now

${ }^{120}$ Id. at 1323 (citation omitted).

${ }^{121} I d$.

128 Id.

${ }^{123}$ Id. at 1324-25. The court further observed that "the California Investors were attempting to evade the final judgments issued by the district court below; they were trying to recover damages they might have received had they not participated in the class action." Id. at 1325.

${ }^{124}$ Id. at 1323 (citing New York Telephone, 434 U.S. at 172).

${ }^{125}$ Id. at 1324. Citing language from Agent Orange II, 996 F.2d 1425, 1431 (2d Cir. 1993), the Seventh Circuit cautioned that its decision should be read narrowly: "In reaching this conclusion, we do not suggest that a court may use the All Writs Act as a 'jurisdictional blank check' to use whenever it deems it advisable. The 'exceptional circumstances' present here ... warrant this proper exercise of judicial discretion." Id. 
seems that resort to the All Writs act is approved not only in civil rights cases, but also "in the context of complex class action litigation, a federal district court may appropriately use the All Writs Act to remove and enjoin the prosecution of subsequent state court claims in order to enforce its ongoing orders against relitigation." ${ }^{126}$ It is a telling measure of how far the law approving removal based on the All Writs Act has come in so few years that the Seventh Circuit in VMS Securities would support its decision without any citation to the trail blazing Yonkers, but instead, would rely heavily on the Second Circuit's later decision in Agent Orange II.

Other courts have broadly interpreted removal authority under the All Writs Act, and not necessarily in a manner consistent with either Yonkers or Agent Orange II. In Harbor Venture, Inc. v. Nichols, for example, the court confronted a challenge to a consent decree previously approved by another judge in the same court twenty years earlier. ${ }^{127}$ The federal consent decree concerned the settlement of a dispute over use of a tract of land in St. Louis County, Missouri. ${ }^{128}$ Twenty years after that consent decree was entered, plaintiffs filed a state court action seeking declaratory judgment to permit a proposed development on the land covered by the consent decree. ${ }^{129}$ The federal district court upheld removal of the case to federal court, asserting that "this Court has the inherent power [sic] that is, automatic ancillary jurisdiction to enforce an agreement when the terms of the settlement have been included in the decree., ${ }^{130}$ The court indicated that it could base its jurisdiction over the removed case either on $\S 1442, \S 1441$ or $\S 1651$. $^{131}$

${ }^{126}$ Id.

127 934 F. Supp. 322 (E.D. Mo. 1996).

${ }^{128}$ See id. at 323 (noting the history of the consent decree at issue in the case).

129 See id. (relating how plaintiffs wanted to build a gambling casino on the land in question).

1so Id.

${ }^{131}$ See id. at 323-24 (finding jurisdiction based on the need to protect the interests of agencies of the United States and their officers, the availability of ancillary jurisdiction over any non-removable claims, and the All Writs Act). According to the court, because agencies of the United States and its officers were defendants in the original federal case and their interests would be implicated in any interpretation of that consent decree, $\S 1442$ mandated removal. Curiously, the only provision of $\S 1442$ that seems even remotely applicable to the situation which was before the court is $\S 1442$ (a) (1); however, $\$ 1442$ (a) (1) only permits removal of a civil action commenced against a United States agency or officer and, in Nichols, no United States agency or official was named as a defendant in the state action. That the interests of such agencies and persons might be implicated by interpretation of the federal consent decree 
Nichols is noteworthy in several respects. First, it does not fall squarely into Type I or Type II. Since the preclusive effect of the federal consent decree was not at issue in the case, Nichols seems more properly characterized as a Type I case. Yet, it is difficult to discern how the subsequent state suit posed a threat to the federal consent decree; rather, it appears that the federal court was only concerned that a Missouri state court judge would not be able to define accurately the parameters of the federal consent decree. ${ }^{132}$ The federal court did not reveal why it had more confidence in its own ability to interpret correctly the meaning of the twenty year old consent decree.

The second noteworthy feature of the Nichols decision is the court's apparent willingness to invoke the All Writs Act in addition to the other statutory removal provisions which it found applicable. More commonly, courts invoke the All Writs Act only when no other adequate means or alternative is available. ${ }^{133}$ This court's decision, however, expressly observed that removal authority also existed under two other statutes. ${ }^{134}$

may suggest that they possessed a right to intervene in the state action, but is not a viable basis for removal under $\$ 1442$ (a)(1).

${ }^{132}$ Even those courts that have accepted the premise that removal may be based on $\$ 1651$ typically have held that a federal court will not remove a state case "where there is only the theoretical potential for inconsistent or conflicting judgments." Atlantic Coast Demolition \& Recycling, Inc. v. Board of Chosen Freeholders, 988 F. Supp. 486, 495 (D.N.J. 1997); see also Pan Atl. Group, Inc. v. Republic Ins. Co., 878 F. Supp. 630, 643-44 (S.D.N.Y. 1995) (refusing to uphold removal of the case pursuant to $\S 1651$ because " $[w]$ hile there is a theoretical potential for inconsistent or conflicting judgments in the state court and federal actions, the realistic likelihood of such an occurrence is small").

${ }^{135}$ See Clinton v. Goldsmith, 67 U.S.L.W. 4302,4305 (U.S. May 17, 1999) (observing that the All Writs Act "invests a court with a power essentially equitable and, as such, [is] not generally available to provide alternatives to other, adequate remedies"); Allied Chem. Corp. v. Daiflon, Inc., 449 U.S. 33, 35 (1980) (observing that "[i]n order to insure that the writ will issue only in extraordinary circumstances, this Court has required that a party seeking issuance have no other adequate means to attain the relief he desires"); Ex Parte Republic of Peru, 318 U.S. 578, 584 (1943) (discussing section 262 of the Judicial Code of 1911 and remarking that the "common law writs, like equitable remedies... are usually denied where other adequate remedy is available"); see also 16 WRIGHT ET AL., supra note 4, § 3933, at 528-29 (observing that "extraordinary relief should be denied when a lesser remedy is adequate"). But see Yonkers Racing Corp. v. City of Yonkers, 858 F.2d 855, 863 (2d Cir. 1988) (suggesting in a discussion of United States Alkali Export Ass'n v. United States, 325 U.S. 196, 201-04 (1945), that the All Writs Act "may be invoked even when another federal statute ordinarily would govern the issue").

${ }^{234}$ See Nichols, 934 F. Supp. at 323-24 (noting that removal was available under 28 U.S.C. $\S 1441$ or $\S 1442$ ). 
Finally, the sheer breadth of the court's holding bears mention. The "threat" which the federal district court apparently perceived to the consent decree must be considered in context. The federal case was brought twenty years earlier, and its conclusion did not follow entry of a judgment by the court based upon adjudicated findings of fact and conclusions of law. Instead, the court simply approved a settlement reached between the parties. Moreover, since the parties (or their predecessors in interest) in the state action were all participants to the consent decree, as the federal district court itself noted, ${ }^{135}$ it is not altogether unreasonable to assume that those parties could have adequately litigated the meaning and scope of the consent decree before a Missouri state court. The decision to uphold removal in Nichols suggests that in the future we will continue to see removal of state cases under the All Writs Act in circumstances even farther afield from the groundbreaking decisions in Yonkers and Agent Orange II.

Third, as discussed more fully in Part III, this broadening of removal jurisdiction is being achieved without reference to the limitations placed upon a party's right to injunctive relief, as established by the existing legal authorities, including the Supreme Court's prior decisions in Parsons Steel, Inc. v. First Alabama Bank ${ }^{136}$ and Chick Kam Choo v. Exxon Comp. ${ }^{137}$ For these reasons, resort to the All Writs Act as a source of removal jurisdiction should be viewed as an improper intrusion in to the state forum. ${ }^{138}$

\section{DO COURTS POSSESS EXISTING JURISDICTION TO SUPPORT REMOVAL UNDER THE ALL WRITS ACT?}

Courts which have approved the use of the All Writs Act as removal authority have frequently maintained that the All Writs Act is a sufficient source of jurisdiction to support removal. The Supreme Court's decision in New York Telephone is typically relied upon to establish that federal courts are infused with inherent removal jurisdiction in $\S 1651$ (a) to protect its prior judgments. ${ }^{139}$ Alternatively, courts

${ }^{135}$ See id. at 323 (noting that "[p]arties in the suit now pending before the Court were all parties in the Volpe case or their predecessors in interest were parties").

${ }^{136} 474$ U.S. 518 (1986).

137486 U.S. 140 (1988).

${ }^{135}$ See infra Part III (arguing that use of the All Writs Act as a source of removal jurisdiction disrupts the balance of state and federal power).

${ }^{139}$ See, e.g., Sable v. General Motors Corp., 90 F.3d 171, 175 (6th Cir. 1996) (citing New York Telephone in support of keeping a case involving EPA-negotiated consent 
have also sought to uphold removal based on the continuing postjudgment. As a result, one important question to answer is whether federal courts possess existing jurisdiction to support removal under the All Writs Act. The first step in this analysis is to look at the historical evidence concerning the enactment of the All Writs Act and the grant of general removal jurisdiction in the First Judiciary Act. The historical record should be examined for any evidence suggesting that the drafters of these statutory provisions contemplated that Congress endowed the lower federal courts with inherent power to remove cases under the All Writs Act. The second step is to consider whether any other sources of jurisdiction, such as the continuing jurisdiction a court possesses after rendering judgment, may support removal pursuant to $\S 1651(a)$. This two-step examination will indicate that the drafters of the original All Writs Act did not intend to invest the inferior federal courts with inherent jurisdiction to uphold a defendant's removal of a state court case, and that no other source of existing jurisdiction can support removal under the statute.

\section{A. Origins and Scope of the All Writs Act}

The statutory ancestors of $\S 1651$ (a) are sections 13 and 14 of the Judiciary Act of 1789 (later combined and incorporated into $\S 1651(a)) .^{140}$ Section 13 of the Judiciary Act of 1789 , an early source of controversy when Chief Justice Marshall declared the provision unconstitutional to the extent it sought to enlarge the Court's original jurisdiction, ${ }^{141}$ also authorized the Supreme Court to issue writs of prohibition to the district courts when acting as a court of admiralty and maritime jurisdiction, as well as writs of mandamus "in cases warranted by the principles and usages of law, to any courts appointed, or

agreements in federal court under the All Writs Act); Lucas v. Planning Bd., 7 F. Supp. 2d 310, 318-19 (S.D.N.Y. 1998) (citing New York Telephone in which the plaintiffs' state court action would interfere with a consent judgment by the federal court); New York State Laborers Political Action Comm. v. Mason Tenders Dist. Council, No. 97-CV1731, 1998 WL 146248, at *5 (N.D.N.Y. Mar. 24, 1998) (citing New York Telephone in support of maintaining jurisdiction in an action involving a prior federally-ordered consent decree); Chance v. Sullivan, 993 F. Supp. 565, 568 (S.D. Tex. 1998) (citing New York Telephome in support of federal jurisdiction where the action concerns a federal court's prior settlement order).

${ }^{140}$ See supra note 4 (discussing the history of $\S 1651$ (a)).

${ }^{111}$ See Marbury v. Madison, 5 U.S. (1 Cranch) 137, 175-80 (1803) (noting that the Constitution allows extension of appellate jurisdiction, not original jurisdiction, by Congress to the Supreme Court). 
persons holding office, under the authority of the United States."112 Section 14 empowered all federal courts to "issue writs of scire facias, habeas corpus, and all other writs not specially provided for by statute, which may be necessary for the exercise of their respective jurisdictions, and agreeable to the principles and usages of law."143 The limiting phrase in section 14, that the writ must be "necessary for the exercise of their respective jurisdictions," is absent from section 13, but was included in the language adopted in $\$ 1651$ (a). The conventional view is that this is a distinction without a difference; ${ }^{144}$ any efforts to attach significance to this difference in language have been frustrated by the absence of any historical evidence indicating legislative intent, as noted by the Supreme Court's observation in Pennsylvania Bureau of Correction v. United States Marshals Service that "it appears that Congress then merely consolidated various provisions into $\S 1651$ and made 'necessary changes in phraseology' without substantive amendment." 145 When Congress enacted the 1948 codification of the Judicial Code, it promulgated $\S 1651$ (a) in its current form. ${ }^{146}$ As a result of the revisions made in 1948 (excepting $\S 2241$ (a) concerning writs of habeas corpus), the All Writs Act is now the only existing statutory

142 Judiciary Act of 1789 , ch. $20, \S 13,1$ Stat. 73, 81 .

14 Judiciary Act of 1789 , ch. $20, \S 14,1$ Stat. 73, 81-82.

144 See 16 WRIGHT ET AL., supra note 4 , $\$ 3933$, at 536-37 (noting that this distinction is "without continuing relevance").

${ }^{145} 474$ U.S. 34,41 (1985).

${ }^{146}$ See 28 U.S.C. § 1651 (a) (1994) (amending 28 U.S.C. \$ 1651(a) (1948)). The 1948 codification consolidated sections 342,376 , and 377 of the 1940 version of the Code which, in turn, were derived from sections 234, 261, and 262 of the Judicial Code of 1911. See Act of March 3, 1911, ch. 231, 36 Stat. 1156, 1162. One difference among the statutory versions is that the phrase "not specifically provided for by statute," found in section 377 of the 1940 version of the Code, was deleted. The legislative history indicates that the changes made were only "necessary changes in phraseology" and not substantive modifications. See 28 U.S.C. \$ 1651(a) (1994) (Reviser's Note). The legislative history also provides that the new section was intended to codify the holding of the Supreme Court in United States Alkali Export Ass'n v. United States, 325 U.S. 196 (1945). See Pennsylvania Bureau of Correction, 474 U.S. at 40 (noting that the legislative history of the 1948 codification of $\$ 1651$ indicates that the new section should be interpreted in line with the Alkali holding). In Alkali, the Court reversed the district court's use of the All Writs Act power, observing that the "writs may not be used as a substitute for an authorized appeal; and where, as here, the statutory scheme permits appellate review of interlocutory orders only on appeal from the final judgment, review by certiorari or other extraordinary writ is not permissible." Alkali, 325 U.S. at 203. Thus, the absence of the phrase "not specifically provided for by statute" has not been interpreted as signaling a broadening of federal court power under $\S 1651$. See Pennsylvania Bureau of Correction, 474 U.S. at $41-42$ (stating that Congress intended to maintain the powers of the federal courts under the All Writs Act, not to expand them). 
authority on which a court may base its issuance of extraordinary writs. ${ }^{147}$

As Justice Powell observed in Pennsylvania Bureau of Correction, there is "scant" historical evidence of legislative discussion about the writ power contained in the two provisions of the Judiciary Act of 1789. ${ }^{148}$ Section 14, drafted by Oliver Ellsworth, was apparently not a topic of controversy in the debates over enactment of the Judiciary Act of $1789 .^{149}$ From a comparison of the final Senate bill and manuscript amendments with the original committee bill, the only changes made in section 14 as prepared by the original judiciary committee appear to have been made by the Senate, which deleted the power to issue "writs of ... subpoena \& protection for witnesses" from the original committee bill..$^{150}$ No other changes to the section have been recorded.

The absence of debate over this provision is revealing in itself. The most likely explanation for the lack of legislative discussion about the writ power contained in sections 13 and 14 is that these provisions were not intended to invest the inferior federal courts, if Congress chose to establish them, with any additional jurisdiction. Opposition to the mere creation of inferior federal courts was strong enough; ${ }^{151}$ the notion that such courts, if created, would be endowed with additional jurisdiction beyond that conferred elsewhere in the Act would no doubt have met with serious opposition. The legislative record

${ }^{117}$ HART AND WECHSLER, supra note 14, at 343 (noting that "the only statutory authority for the issuance of the extraordinary writs ... is ... the famous all-writs section-now 28 U.S.C. $\$ 1651$ (a)").

${ }^{163}$ Pennsylvania Bureau of Correction, 474 U.S. at 41.

149 See THE DOCUMENTARY HISTORY OF THE SUPREME COURT OF THE UNITED STATES, 1789-1800, ORGANIZING THE FEDERAL JUDICIARY: LEGISLATION AND COMMENTARIES, at 36 (Maeva Marcus et al. eds., 1992) [hereinafter DOCUMENTARY HISTORY OF THE SUPREME COURT] (noting that "sections 10-24 [of the original Senate bill of the Judiciary Act] are in Oliver Ellsworth's hand").

${ }_{150}$ See id. at 71 (noting the differences between the original Senate bill and the Act). Early commentary diverges, however, over when this change in the language of section 14 was made. See Charles Warren, New Light on the History of the Federal Judiciary Act of 1789, 37 HARV. L. REV. 49, 95 (1923) (observing that the "express power to issue a writ of 'subpoena and protection for witnesses' was stricken" by the Senate); see also JuluUs GoEbel, JR., THE OLIVER WENDELl HOLMES DEVISE HISTORY OF THE SUPREME COURT OF THE UNITED STATES: ANTECEDENTS AND BEGINNINGS TO 1801478 (1971) (remarking that the "Committee's working draft had added writs of subpoena and protections of witnesses, but this was struck before the bill reached final form").

${ }^{152}$ For an excellent historical account of the debates surrounding establishment of the inferior federal courts, see DOCUMENTARY HISTORY OF THE SUPREME COURT, supra note 149 , at $1-38$. 
contains no evidence that the writ power in sections 13 and 14 was intended to be anything more than a power given to the Supreme Court and all other courts Congress chose to create to enforce the limited jurisdiction they would possess. The absence of debate over the writ power contained in these two provisions is understandable. While there was considerable debate over whether lower federal courts should be created at all, and if created, what the extent of their jurisdiction should be, the notion that a federal court, once created, would be vested with writ power to aid its existing jurisdiction would have been considered unremarkable. ${ }^{152}$

Early Supreme Court decisions concerning this writ power similarly suggest that the intent of the drafters was not to expand federal court jurisdiction through these provisions. Thus, in McIntire v. Wood, the Court's earliest pronouncement on the scope of section 14, the Court ruled that the federal courts were without power to issue a writ of mandamus to the register of a state land office. ${ }^{153}$ The case did not come within the original jurisdiction of the federal courts because Congress had not enacted legislation that extended federal jurisdiction that far, even though the case did fall within the judicial power of Article III. ${ }^{154}$ Because no independent source of jurisdiction existed, and because federal court power to issue writs of mandamus "is confined exclusively to those cases in which it may be necessary to the exercise of their jurisdiction," the Court held that issuance of the mandamus was improper. ${ }^{155}$ Here, then, in the Court's first declaration of the scope of the writ power in section 14, is a definitive recognition by the judiciary that the legislative provision was not intended to be an independent source of jurisdiction. The Supreme Court reiterated this ruling eight years later in McClung $v$. Silliman. ${ }^{156}$ Thus, congressional enactment of sections 13 and 14 of the Judiciary Act of 1789, as well as early Supreme Court interpretation of these provisions,

${ }^{152}$ See Edward S. Corwin, Marbury v. Madison and the Doctrine of Judicial Review, 12 MrCH. L. REV. 538, 541-42 (1914) (describing section 13 and remarking that in Common Law practice ... the writ of mandamus was not, ordinarily at least, an instrument of obtaining jurisdiction by a court, even upon appeal, but like the writs of habeas corpus and injunction, was a remedy available from a court in the exercise of its standing jurisdiction").

153 11 U.S. (7 Cranch) 503, 504 (1813).

${ }^{154}$ See id. (holding that the Court lacked jurisdiction because of the absence of a statute specifically conferring jurisdiction).

${ }^{155}$ Id.

15619 U.S. (6 Wheat.) 598 (1821). 
strongly suggests that Congress intended the power to issue writs to be "derivative" of jurisdiction previously established. ${ }^{157}$

In addition to the historical evidence concerning the All Writs Act, the grant of general removal jurisdiction by Congress in the Judiciary Act of 1789 further supports the view that the All Writs Act was not intended as a source of removal authority. No provision in the Constitution authorizes federal courts to exercise removal jurisdiction. The removal power of federal courts was first promulgated by Congress in the Judiciary Act of $1789 .{ }^{158}$ Since then, statutory removal jurisdiction has existed over any case which would have been within the judicial power of the United States had it been brought originally in a federal court. ${ }^{159}$ To justify its existence, removal jurisdiction has been upheld under Article I's "necessary and proper" clause, ${ }^{160}$ principally on the authority of two early Supreme Court decisions, Tennessee $v$. Davis $^{161}$ and Martin v. Hunter's Lessee. ${ }^{162}$ It has been observed that removal jurisdiction may constitute an exception to the general principle that the jurisdiction of the federal courts cannot be broadened beyond the Constitution. ${ }^{163}$ Yet, the power of removal does not constitute a grant of jurisdiction beyond the limits of Article III. To be precise, removal power is merely a procedural device in aid of jurisdiction made available by Congress to the federal courts, not a grant of additional jurisdiction. Ninety years after Congress first endowed federal

${ }^{157}$ It also has been argued by Professor Akhil Reed Amar, based on the language of the Judiciary Act of 1789, that section 14 was not intended to be a source of original jurisdiction. Professor Amar points out that sections 14, 15, and 17 of the First Judiciary Act reveal a distinction between the word "power" and "jurisdiction." Thus, in section 14, federal courts have the "power" to issue writs which may be necessary for the exercise of their respective "jurisdictions." Amar, supra note 4, at 457-58. Parsing the Act's text in this manner, Professor Amar concludes "it is clear from context that the Act is investing courts with certain authority if and when they have independently founded jurisdiction.... 'Jurisdiction' must be established first, and independently; 'power' then follows, derivatively." Id. at 458.

${ }_{159}^{153}$ Judiciary Act of 1789 , ch. 20, § 12, 1 Stat. 73, 79-80 (1789).

159 See 13 WRIGHT ET AL., supra note $13, \S 3521$, at $53-54$ (noting that removal statutes have permitted removal from state to federal courts in certain circumstances despite the fact that the Constitution does not specifically allow such removal).

${ }^{160}$ See id. at 54 (stating that removal jurisdiction is an "appropriate exercise of the congressional power to make laws 'necessary and proper' for carrying out the tasks delegated to the national government").

${ }_{161} 100$ U.S. 257 (1879).

162 14 U.S. (1 Wheat.) 304 (1816).

${ }^{163}$ See 13 WRIGHT ET AL., supra note 13, § 3521, at 53 (noting the erosion of the principle that federal court jurisdiction cannot extend beyond that given in the Constitution). 
courts with removal authority, the Court in Tennessee $v$. Davis upheld removal power as a proper exercise of congressional power under the "necessary and proper" clause of Article I. In his opinion for the Court, Justice Strong commented that " $[t]$ he constitutional right of Congress to authorize the removal before trial of civil cases arising under the laws of the United States has long since passed beyond doubt." ${ }^{\text {}}$ Justice Strong found historical support for the practice to be significant:

[Removal power in civil cases] was exercised almost contemporaneously with the adoption of the Constitution, and the power has been in constant use ever since. The Judiciary Act of Sept. 24, 1789, was passed by the first Congress, many members of which had assisted in framing the Constitution; and though some doubts were soon after suggested whether cases could be removed from [s] tate courts before trial, those doubts soon disappeared. ${ }^{165}$

A federal court's authority to exercise judicial power over a case removed from state court, then, is consistent with the constitutional grant of jurisdiction and is not an additional grant of jurisdiction. Article III, section 2 lists the kinds of cases coming within the federal judicial power; it does not address or attempt to set any boundaries on the manner in which federal courts may assume jurisdiction over a case. ${ }^{166}$ Removal power, properly understood, is a procedural device by which a case coming within the ambit of Article III may be brought into federal court. If a state case is one that "would have been within the judicial power of the United States had it been brought originally in a federal court," ${ }^{167}$ then it is always an Article III case, regardless of the forum in which it is filed. Consequently, a court's removal jurisdiction is, and can only be, coterminous with the limits of Article III.

If Congress never intended the original grant of removal jurisdiction to extend the jurisdiction of the lower federal courts beyond Arti-

${ }^{164}$ Davis, 100 U.S. at 265.

${ }^{165} I d$.

${ }^{166}$ Other statutes govern the manner by which a case may be removed to federal court. See, e.g., 28 U.S.C. $\$ 1446$ (b) (1994) (providing that the notice of removal must be filed within thirty days after the receipt by the defendant of a copy of the initial pleading setting forth the claim for relief). Untimely notice of removal may cause a party to waive its right to the federal forum; however, $\$ 1446(\mathrm{~b})$ does not alter the underlying character of the case. See id. (failing to change a case from a federal to a state case just because the federal forum is waived). A case coming within Article III remains an Article III case, even though the defendant may have waived its right to remove the case to federal court.

${ }^{167} 13$ WRIGHT ET AL., supra note $13, \S 3521$, at 53-54. 
cle III, then the argument for now upholding removal of non-Article III cases pursuant to some special removal power within the All Writs Act is substantially undercut. To permit removal by $\S 1651$ (a) would constitute an end run around the legislature's determination that the jurisdictional reach of the federal courts should not extend so broadly. While Congress may be able to expand that jurisdiction beyond its current limits, it has never done so.

One final, compelling argument can be made that the original All Writs Act section of the First Judiciary Act was not intended as a basis for additional removal jurisdiction. The First Judiciary Act specifically granted courts general removal jurisdiction in section 12. Yet, no mention is made in that provision of any additional writ power of removal. ${ }^{168}$ Following the approach that provisions in the same statute must be construed together (that is, in pari materia), ${ }^{169}$ it can be posited that drafters must not have meant to empower federal courts in section 14 with additional removal authority since the power to remove a narrow class of cases was given explicitly in section 12. The limited circumstances in which removal of a state case was allowed by section 12 cannot be squared with the notion that the drafters-without explicitly saying so-also enacted a general, residual grant of removal jurisdiction in section 14 . Neither the legislative history of section 14 nor the plain language of the statute reveals any evidence of congressional intent to vest federal courts with jurisdiction to uphold removal of a non-Article III case pursuant to $\S 1651$ (a).

\section{B. May Removal Jurisdiction Be Based on the Court's Original Jurisdiction to Enforce Its Original Judgment?}

In the absence of any historical evidence of congressional intent to endow federal courts with jurisdiction to exercise judicial power over cases removed pursuant to the All Writs Act, the next question is whether the original jurisdiction possessed by federal courts in entering judgments subsequently implicated by state cases is sufficient to establish subject matter jurisdiction over cases removed pursuant to the All Writs Act. Even if the historical record establishes that Congress did not directly grant the courts any jurisdiction in the All Writs

${ }^{163}$ See Judiciary Act of 1789 , ch. 20, § 12, l Stat. 73, 79-80 (1789).

${ }^{169}$ For a description of several methods of statutory construction followed by the Supreme Court at various times, see Michael E. Solimine, Removal, Remands, and Reforming Federal Appellate Revieus 58 MO. L. REV. 287, 297-301 (1993). 
Act, it could be argued that the original jurisdiction possessed by the federal court may serve as the basis for jurisdiction over the removed actions. In VMS Securities, for example, a panel of the Seventh Circuit upheld use of the All Writs Act to remove a subsequent state action which was described as constituting a threat to the judgments entered in two related federal district court cases. ${ }^{170}$ Because "the district court retained jurisdiction over both actions, it could properly remove the California [state plaintiffs'] claims from California state court pursuant to the All Writs Act." ${ }^{171}$ According to the panel, the "essence of this case is the continuing jurisdiction of the federal court to enforce and protect its own judgments." 172

Less than three months earlier, another panel of the Seventh Circuit declined to find ancillary removal jurisdiction based upon the continuing jurisdiction of a prior federal court to enforce its orders in In re County Collector. ${ }^{173}$ In a 2-1 decision, the Seventh Circuit panel declined to uphold removal pursuant to the All Writs Act of state tax suits challenging the levy of property taxes. The defendants argued that if the tax suits were successful, they would frustrate the implementation of a prior federal consent decree directing the school district to remedy racial discrimination by levying additional taxes. In his opinion, Judge Flaum observed that the school district, in removing the tax suits, was "attempting to use the writ to confer a jurisdiction which the district court would not have without it."174 The court did not reach the "difficult issue of whether the All Writs Act can ever create removal jurisdiction over a case. ${ }^{175}$ Judge Flaum wrote that because the consent decree was entered without findings of "liability" or "necessity," the All Writs Act could not serve as a basis for removal of the state tax cases. ${ }^{176}$ The opinion suggests that the school district's removal argument, if accepted, would create a "limited form of ancillary removal jurisdiction." 177 Notwithstanding the reluctance of the court in County Collector, several other courts, like the court in VMS Securities, have posited that ancillary removal jurisdiction may satisfy the subject matter jurisdiction requirements for a case removed under the

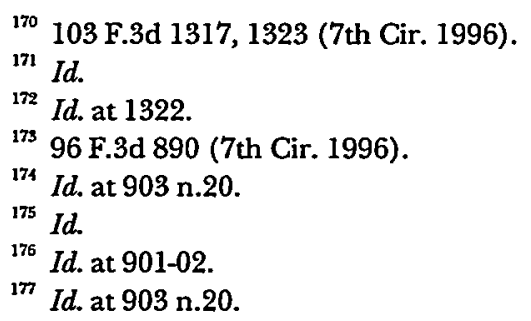


All Writs Act. ${ }^{178}$

Even if the federal court's original jurisdiction over the parties could be a valid source for establishing subject matter jurisdiction over the removed case, this theory of ancillary removal jurisdiction would have limited application in practice. If the contention is that removal under $\S 1651$ (a) may be established through the jurisdiction originally possessed by a federal court in issuing a prior order, then under the current statutes, only the court issuing the prior order would have jurisdiction to exercise judicial power over a removed case. ${ }^{179}$ Section 1441 (a) permits a defendant to remove a case only "to the district court of the United States for the district and division embracing the place where such action is pending. ${ }^{180}$ Section 1651(a), of course, contains no comparable internal venue provision. ${ }^{181}$ Thus, to the extent that the Second Circuit's decision in Agent Orange II was predicated on this theory of ancillary removal jurisdiction, ${ }^{182}$ removal of the Texas state action by the federal court in Texas should have been considered inappropriate. Only the Eastern District of New York

${ }^{178}$ See, e.g., Yonkers Racing Corp. v. City of Yonkers, 858 F.2d 855, 863 (2d Cir. 1988) (arguing that the All Writs Act authorizes removal where it is "necessary or appropriate to effectuate and prevent the frustration of orders [a court] has previously issued in its exercise of jurisdiction otherwise obtained" (quoting United States v. New York Tel. Co., 434 U.S. 159, 172 (1977))); Neuman v. Goldberg, 159 B.R. 681, 685 (S.D.N.Y. 1993) ("The All-Writs Act gives federal courts sweeping authority to preserve their jurisdiction over complex, ongoing litigation ....").

${ }^{179}$ See Hillman v. Webley, 115 F.3d 1461, 1469-70 n.6 (10th Gir. 1997) (noting that where the federal district court in Colorado approved a settlement, removal of a subsequently filed California state action would only have been proper to the federal district court in California pursuant to $\$ 1441$ ).

${ }^{180} 28$ U.S.C. $\$ 1441$ (a) (1994).

${ }^{181}$ Perhaps Congress could amend the statute to include a venue component, although that seems highly unlikely. The point here is that through the current practice of upholding removals by the All Writs Act, courts have grafted onto the Act not only additional jurisdictional but also venue authority as well, neither of which the current Act supports.

${ }^{182}$ It is not clear from the opinion whether the Second Circuit relied on the original jurisdiction of Judge Weinstein to establish subject matter jurisdiction over the removed cases. Other courts interpreting the decision in Agent Orange II have certainly assumed that the Second Circuit used this ancillary jurisdiction to satisfy the subject matter jurisdiction requirements over the removed cases. See, e.g., In re VMS Sec. Litig., 103 F.3d 1317, 1324 (7th Cir. 1996) (observing that in Agent Orange II "the district court expressly retained jurisdiction over the maintenance, distribution, and administration of the settlement fund," and that the Second Circuit had reasoned that "the district court had the right to enforce its "explicit, ongoing order against relitigation of matters it already had decided" (quoting Agent Orange II, 996 F.2d 1425, 1431 (2d Cir. 1993))). 
may have possessed ancillary jurisdiction to protect its prior order and been a court of proper venue. Based on the current statutes, then, ancillary removal jurisdiction is a theory of limited practical application for justifying removal authority under the All Writs Act.

But is the theory fundamentally sound, even within this limited scope? Is it permissible for the original federal court whose judgment is now threatened to exercise judicial power over a case removed from state court by $\S 1651$ (a) and thereby protect its prior decree? The argument in favor of removal in this narrow category of cases is tempting but ultimately untenable. The Supreme Court in Peacock v. Thomas was invited to base subject matter jurisdiction on the ancillary jurisdiction possessed by the federal court in an earlier case; the Court, however, declined the invitation. ${ }^{183}$ In Peacock, Jack Thomas filed an ERISA class action against his former employer and one of its principal officers, D. Grant Peacock, in federal court, alleging that they had breached their fiduciary duties to the class in administering the company's pension benefits plan. The district court found that the company had breached its fiduciary duties and entered judgment against it. ${ }^{184}$ The district court also determined that the officer, D. Grant Peacock, was not a fiduciary and granted judgment in Peacock's favor on all of Thomas' claims. When Thomas was unable to collect on the federal judgment against the company, he sued Peacock in federal court again, this time asserting that Peacock had conspired with the company to prevent satisfaction of the judgment. Thomas also sought to pierce the corporate veil to reach Peacock. ${ }^{185}$ No federal claims were brought in this second action, however, and Peacock challenged the jurisdiction of the court to hear the case. The district court granted judgment against Peacock, finding that it was proper to pierce the corporate veil. The circuit court affirmed, specifically ruling that the district court had ancillary jurisdiction to hear the second case against Peacock. ${ }^{186}$

On appeal, the Supreme Court reversed the decision of the lower court. Citing its earlier decision in Kokkonen v. Guardian Life Insurance

${ }^{183}$ See 516 U.S. 349, 351 (1996) (holding that federal courts do not "possess ancillary jurisdiction over new actions in which a federal judgment creditor seeks to impose liability for a money judgment on a person not otherwise liable").

${ }^{184}$ See id. at 351 (noting the district court's holding).

${ }^{185}$ See id. at 352 (noting that Thomas amended his complaint, asserting a claim for "Piercing the Corporate Veil Under ERISA and Applicable Federal Law").

${ }^{186}$ See id. (noting that the court of appeals held that the district court properly exercised ancillary jurisdiction over Thomas's suit). 
Co. of America, ${ }^{187}$ the Court's most recent statement on the scope of the ancillary jurisdiction power of the federal courts, the Court observed that "a federal court may exercise ancillary jurisdiction: '(1) to permit disposition by a single court of claims that are, in varying respects and degrees, factually interdependent; and (2) to enable a court to function successfully, that is, to manage its proceedings, vindicate its authority, and effectuate its decrees." ${ }^{\text {18s }}$ The Court found, however, that exercise of jurisdiction over Peacock would be inappropriate under either category. The Court rejected the first prong of ancillary jurisdiction from Kokkonen because the claims were not brought in one lawsuit:

In a subsequent lawsuit involving claims with no independent basis for jurisdiction, a federal court lacks the threshold jurisdictional power that exists when ancillary claims are asserted in the same proceeding as the claims conferring federal jurisdiction. Consequently, claims alleged to be factually interdependent with and, hence, ancillary to claims brought in an earlier federal lawsuit will not support federal jurisdiction over a subsequent lawsuit. ${ }^{189}$

When a subsequent lawsuit is involved, the rationale for the ancillary jurisdiction doctrine, which is based on the need "to protect legal rights or effectively to resolve an entire, logically entwined lawsuit," is not applicable. ${ }^{190}$

The second reason articulated by Kokkonen for exercising ancillary jurisdiction initially seemed to be compelling on the facts in Peacock. "Without jurisdiction to enforce a judgment entered by a federal court, 'the judicial power would be incomplete and entirely inadequate to the purposes for which it was conferred by the Constitution.' ${ }^{191}$ Following this doctrine, ancillary jurisdiction is properly exercised, then, if the continuing jurisdiction of the court is necessary to protect and enforce the prior federal judgment. In Peacock, however, the Court found that ancillary jurisdiction was not necessary to protect the prior federal judgment Thomas obtained against his employer, primarily because the new action he had brought against Peacock posited new legal theories of recovery. ${ }^{192}$

\footnotetext{
${ }^{187} 511$ U.S. 375 (1994).

${ }^{183}$ Peacock, 516 U.S. at 354 (quoting Kokkonen, 511 U.S. at 379-80).

${ }^{189} \mathrm{Id}$. at 355 (citations omitted).

${ }^{190}$ Id. (quoting Owen Equip. \& Erection Co. v. Kroger, 437 U.S. 365, 377 (1978)).

191 Id. at 356 (quoting Riggs v. Johnson County, 73 U.S. (6 Wall.) 166, 187 (1868)).

192 See id. at 358-59 (explaining that the new action based on alleged wrongdoing occurred after the judgment was entered and involved new theories of liability that
} 
Applying the lesson of Peacock to the question of $\$ 1651$ (a) ancillary removal jurisdiction, the original jurisdiction possessed by the federal court in issuing a judgment should be insufficient to satisfy the subject matter requirements in a case removed solely pursuant to the All Writs Act. A case removed from state court only on the basis of the All Writs Act is a subsequent lawsuit "involving claims with no independent basis for jurisdiction." ${ }^{\text {193 }}$ Consequently, under the first Kokkonen prong as interpreted by Peacock, subject matter jurisdiction requirements in the removed state action cannot be satisfied by the jurisdiction possessed in the original federal case. ${ }^{194}$ Furthermore, under the second rationale for ancillary jurisdiction in Kokkonen, the exercise of ancillary jurisdiction must be necessary for the court to function and manage its proceedings. ${ }^{195}$ As the Court noted in Peacock, "[a]ncillary... jurisdiction is, at its core, a creature of necessity." 196

Removal under the All Writs Act, however, cannot be said to be "necessary" to protect a prior federal judgment since it is not the only, or even the most potent, procedural weapon to combat an attack on a federal decree. One option is for the federal court to protect the prior judgment by deferring to the state court, thus allowing the defendant to file an affirmative defense of res judicata and seek summary dismissal of the plaintiff's state claim before the state tribunal. Alternatively, when appropriate under the relitigation exception to the Anti-Injunction Act, a federal court may enjoin the state court action from interfering with an earlier federal decree. ${ }^{197}$ Consequently, because these other procedural remedies exist, removal cannot be said to be "necessary" to preserve the federal judgment. It follows that under the second prong of ancillary jurisdiction from Kokkonen, the jurisdiction the federal court originally possessed cannot serve as the subject matter basis over the removed state action. ${ }^{198}$ Because an ac-

were not asserted in the previous lawsuit).

${ }^{193}$ Id. at 355.

194 See id. at 356 (holding that the cases have neither logical nor factual interdependence, so that no greater efficiencies will result from exercising federal jurisdiction).

195 See Kokkonen, 511 U.S. at 380 (holding that ancillary jurisdiction must be predicated on the court's need to "protect its proceedings and vindicate its authority").

${ }^{196}$ Peacock, 516 U.S. at 359.

197 See infra text accompanying notes 273-303 (describing a federal court's limited ability to enjoin a state court's action).

${ }^{193}$ See Kokkonen, 511 U.S. at $380-81$ (asserting that ancillary jurisdiction must be necessary to protect a court's proceedings and its authority). The requirement that 
tion removed under $\S 1651$ (a) will necessarily lack an independent basis for jurisdiction (otherwise, one of the traditional removal statutes would be used), the jurisdiction the court possessed in an earlier action cannot satisfy the subject matter jurisdiction requirements for a case removed under the All Writs Act.

\section{PRotecting Federal Judgments: Preclusion LAW AND THE ANTI-INJUNCTION ACT}

I have demonstrated that the All Writs Act was not intended to serve as an independent basis of jurisdiction over a case removed from state to federal court. In this final Part, I will defend the second conclusion of this study, that the expansive use of the All Writs Act as a source of removal jurisdiction interferes with the balance of state and federal relations in a manner which neither the Congress nor the Court has approved or likely would approve.

Through enactment and development of a number of different legal rules and doctrines-both statutory and judge-made-Congress and the Supreme Court have attempted to provide a general framework to guide the determination of when federal intervention in sovereign state judicial proceedings to protect and effectuate a prior federal judgment is appropriate. These authorities, of course, were enacted and promulgated at different times and for different purposes. For instance, the Federal Full Faith and Credit statute, ${ }^{199}$ and various federal abstention doctrines, ${ }^{200}$ are grounded in principles of federalism and comity, and counsel deference to state courts. Other authorities, like the relitigation exception to the Anti-Injunction $\mathrm{Act}^{201}$ recognize that circumstances may arise that warrant federal intervention to protect federal judgments. Moreover, debate continues

the exercise of ancillary jurisdiction must be necessary for the court to manage its affairs is also consistent with the Supreme Court's pronouncement in New York Telephone that the All Writs Act is only properly invoked to effectuate a court's orders if it is necessary as the only available alternative. See New York Telephone, 434 U.S. at 172-73 (1977) (recognizing that the All Writs Act may be used when "necessary or appropriate to effectuate and prevent the frustration of orders [a court] has previously issued").

28 U.S.C. \$ 1738 (1994).

${ }^{200}$ For a thorough discussion of the various abstention doctrines that may be relevant when a federal judgment is implicated by subsequent state proceedings, see HART \& WECHSLER, supra note 14, at 1230-56 (describing abstention doctrines and their role in limiting the jurisdiction of the federal courts).

${ }^{201}$ See 28 U.S.C. $\$ 2283$ (1994) (stating that a federal court may stay proceedings in a state court when authorized by Congress, to aid in its jurisdiction, and to protect its judgments). 
over how each of these rules and doctrines should be applied. Specifically, there is disagreement over how much authority state courts should possess in rendering decisions which may impact federal law and federal judgments. ${ }^{202}$ I do not defend the current system. I contend, however, that the practice adopted by a few circuit courts and a number of district courts in grounding removal jurisdiction on $\S 1651$ (a) is inconsistent with the current system.

Judicial expansion of the All Writs Act as independent removal authority may be explained, in large part, by the inability of the Court and Congress to articulate coherent guidelines for federal intervention in state court proceedings. Consider, for instance, the implications of the rule from Parsons Steel, Inc. v. First Alabama Bank ${ }^{203}$ Following the decision in Parsons Steel, a federal court may enjoin state proceedings until the time that the state court renders a preclusion determination which is final under the state's preclusion law. Thereafter, $\S 1738$ obligates the federal court to give credit to the state judgment. ${ }^{204}$ If a defendant is entitled to federal injunctive relief under Parsons Steel, it might not seem unreasonable to think that the defendant would also be entitled to remove the state case to federal court on the basis of a preclusion defense. Indeed, the Court's language and articulated reasoning, particularly when read along with its decision in Moitie, opened the door to such an interpretation. As we now know from the Court's recent decision in Rivet v. Regions Bank, ${ }^{205}$ however, this is not the proper reading of Parsons Steel.

In a similar fashion, congressional enactment and judicial interpretation of the exceptions to the Anti-Injunction Act have significantly relaxed the more stringent proscription against federal intervention which the original Act provided. ${ }^{206}$ As a result, two antithetical principles now coexist in the same statute: honoring deference to the state court, on the one hand, and recognizing the necessity for federal

${ }^{202}$ For a discussion on the parity debate and a list of related authorities, see HART \& WECHSLER, supra note 14, at 351-54 (describing various aspects of the parity debate, including a discussion of the "parity" or "disparity" of state and federal courts).

${ }^{203} 474$ U.S. 518 (1986).

${ }^{204}$ See id. at 524 (holding that once a state court rejects a claim of res judicata, the Full Faith and Credit Act becomes applicable and federal courts must make a determination based on state law).

${ }^{205} 522$ U.S. 470,478 (1998) (holding that claim preclusion by reason of a prior federal judgment provides no basis for removal).

206 See, e.g., HART \& WECHSLER, supra note 14, at 1201-07 (noting congressionally and judicially imposed limitations on the scope of the Anti-Injunction Act). 
injunctive relief, on the other. Thus, it may cogently be asked, if under one of the exceptions to the Anti-Injunction Act a state court suit may be properly enjoined, why should a federal court not be able to exercise judicial power pursuant to the All Writs Act over a state case brought to it by removal? If a federal court issues an injunction suspending state court proceedings in circumstances permitted by $\S 2283$, has it interfered any more or less than if it had upheld a defendant's removal of the state action to federal court by $\S 1651$ (a)?

In her recent study of federal arbitral antisuit injunctions, Professor Jean Sternlight lists numerous authorities that may be relevant whenever a federal judgment may be affected by state court litigation. ${ }^{207}$ Additional authorities that could be added to the list include the non-binding but influential Restatement (Second) of Judgments, ${ }^{208}$ the due process clauses of the Fifth and Fourteenth Amendments, ${ }^{209}$ the Supremacy Clause, ${ }^{210}$ and general principles of federalism and comity. ${ }^{211}$ As though this lengthy litany were not daunting enough, authorities governing the choice of law questions in preclu-

${ }^{207}$ See Jean Sternlight, Arbilral Antisuit Injunctions, 147 U. PA. L. REV. 91,96 (1998) (citing federal arbitral antisuit injunctions for their practical significance and for the intriguing jurisdictional questions they raise). The author's list includes the Federal Full Faith and Credit Statute, 28 U.S.C. § 1738 (1994); principles of claim and issue preclusion; the Rooker-Feldman doctrine; the All Writs Act, 28 U.S.C. § 1651 (a) (1994); traditional equitable principles; the Anti-Injunction Act, 28 U.S.C. $\$ 2283$ (1994); and various abstention doctrines. See also Diane P. Wood, Fine-Tuning Judicial Federalism: $A$ Proposal for Reform of the Anti-Injunction Act, 1990 BYU L. REv. 289, 290-91 (1990), for a discussion on how the Anti-Injunction Act relates to general jurisdictional and equitable rules. Wood observes:

[T] he Anti-Injunction Act is actually just one of several devices designed to assure the proper allocation of judicial business between the state and federal courts. The Act shares that task most prominently with the abstention doctrines, and to a lesser extent, with a variety of other doctrines, including jurisdiction of the federal courts, the removal power, the ebbs and flows of pendent and ancillary jurisdiction, with the Rooker-Feldman doctrine, and the rules of intersystem preclusion.

Id.

${ }^{209}$ RESTATEMENT (SECOND) OFJUDGMENTS (1982).

${ }^{209}$ The general due process guarantees have been interpreted to impose strict limits on the preclusive effects of judgments. Compare U.S. CoNST. amends. V \& XIV, § 1 (restricting courts from precluding parties without affording them due process of law), with Parklane Hosiery Co. v. Shore, 439 U.S. 322, 327 n.7 (1979) (observing that it would be "a violation of due process for a judgment to be binding on a litigant who was not a party or a privy and therefore has never had an opportunity to be heard").

${ }^{210}$ U.S. CONST. art. VI, cl. 2.

211 See, e.g., HART \& WECHSLER, supra note 14, at 1222-30 (raising the issues of comity and federalism as limitations of federal court jurisdiction). 
sion law analysis must also be considered. ${ }^{212}$ Trying to canvass and apply all of these legal rules and judicial doctrines can be a daunting, if not overwhelming, task for courts and litigants.

I will not examine in detail all of these legal rules and judicial doctrines, but instead focus on two common procedural methods available for protecting federal judgments. The first method for protecting federal judgments is by state courts applying preclusion law to determine the preclusive effect of a prior federal judgment. ${ }^{213}$ The second method, though a less common method by far, is the protection of federal judgments by federal courts through the issuance of injunctive relief. . $^{214}$

My discussion will not detail all of the legal rules and judicial doctrines that may be relevant when a federal judgment is implicated in subsequent state proceedings for several reasons. For one, such an undertaking would take us well beyond the subject of $\S 1651$ (a) removal cases. More importantly, because the determination of when a state court is to be left alone to make a preclusion law ruling has a direct impact on the availability of injunctive relief under the AntiInjunction Act, the Court's preclusion law decisions and the Act are, in many respects, different sides of the same coin. Finally and relatedly, by considering application of preclusion law by state courts alongside the availability of injunctive relief from federal courts, the fundamental tension that exists when federal judgments are implicated in subsequent state proceedings is brought into sharp focus: how to respect the sovereignty of independent state tribunals without compromising enforcement and effectuation of prior federal judgments.

${ }^{212}$ For two of the most thorough examinations of the choice of law issues which can arise in interjurisdictional contexts, see Stephen B. Burbank, Interjurisdictional Preclusion, Full Faith and Credit and Federal Common Law: A General Approach, 71 CORNELL L. REV. 733 (1986) (discussing interjurisdictional preclusion, particularly concerning the choice of prelusion law, in light of the realities of litigation) and Howard $M$. Erichson, Interjurisdictional Preclusion, 96 MICH. L. REV. 945 (1998) (focusing on the binding effect of a judgment as a matter of claim and issue preclusion).

${ }^{213}$ See infra text accompanying notes 228-55 (describing the deference that should be paid to state courts to determine the issue of preclusion).

${ }^{214}$ See infra text accompanying notes 273-90 (examining the historical evolution of the Anti-Injunction Act and the resulting right of federal courts to issue injunctive relief in specific situations). 


\section{A. State Preclusion Law and the Anti-Injunction Act}

In our constitutional system, state courts must adjudicate federal law issues. "In the scheme of the Constitution," Professor Henry Hart once observed, the state courts "are the primary guarantors of constitutional rights, and in many cases they may be the ultimate ones." ${ }^{215}$ Debate may exist over the relative parity of state and federal courts, ${ }^{216}$ and there may be little agreement over how to allocate power between different sovereign judicial systems, but the Supreme Court has recognized that as long as litigants are given the choice of filing suit in either the state or federal forum (as they are most of the time), ${ }^{217}$ state courts will continue to play a significant role as arbiters of federal law issues. $^{218}$ Indeed, the Court has emphasized the important role of state courts in adjudicating federal law issues on numerous occasions. In Tafflin v. Levitt, ${ }^{219}$ for instance, in granting certiorari on the question of whether state courts have concurrent jurisdiction over civil actions brought under the Racketeer Influenced and Corrupt Organizations Act, ${ }^{220}$ the Court observed:

We begin with the axiom that, under our federal system, the States possess sovereignty concurrent with that of the Federal Government, subject

${ }^{215}$ Henry M. Hart, Jr., The Power of Congress to Limit the Jurisdiction of Federal Courts: An Exercise in Dialectic, 66 HARV. L. REV. 1362, 1401 (1953).

${ }^{216}$ See Burt Neuborne, The Myth of Parity, 90 HARv. L. REv. 1105, 1124 (1977) (arguing, inter alia, that federal courts better protect federal constitutional rights because "an elite tradition animates the federal judiciary, instilling elan and a sense of mission in federal judges"). Others have noted, however, that the empirical evidence does not support the claim that state court judges refuse to enforce Supreme Court mandates. See, e.g., Michael E. Solimine \& James L. Walker, Constitutional Litigation in Federal and State Courts: An Empirical Analysis of Judicial Parity, 10 HASTINGS CONST. L.Q. 213, 229 n.79 (1983) (citing and discussing several empirical studies). See generally HART \& WECHSLER, supra note 14 at 351-54 (noting that the parity debate can actually be broken down into separate issues: (i) "[p]arity as an empirical or sociological concept[:] whether state courts-in fact and on average-are as fair and as competent as federal courts," and (ii) "[p]arity as a [c]onstitutional [c]oncept[:] ... whether the Constitution (and Article III in particular) is indifferent whether adjudication occurs in a federal court or a state court").

${ }_{217}^{217}$ See Charles Dowd Box Co. v. Courtney, 368 U.S. 502, 507-08 (1962) (noting that "[c]oncurrent jurisdiction has been a common phenomenon in our judicial history, and exclusive federal court jurisdiction over cases arising under federal law has been the exception rather than the rule").

${ }^{218}$ See Claflin v. Houseman, 93 U.S. 130, 136 (1876) (remarking that "if exclusive jurisdiction be neither express nor implied, the State courts have concurrent jurisdiction whenever, by their own constitution, they are competent to take it").

${ }^{219} 493$ U.S. 455 (1990).

${ }^{220} 18$ U.S.C. $\$ \S 1961-68$ (1994). 
only to limitations imposed by the Supremacy Clause. Under this system of dual sovereignty, we have consistently held that state courts have inherent authority, and are thus presumptively competent, to adjudicate claims arising under the laws of the United States.

In Stone v. Powell, a Fourth Amendment case, the Court similarly rejected the argument that federal courts are necessarily always better protectors of federal constitutional rights than state courts. ${ }^{222}$ The Court emphasized that "state courts, like federal courts, have a constitutional obligation to safeguard personal liberties and to uphold federal law. ${ }^{223}$ In Amalgamated Clothing Workers $v$. Richman Brothers Co., the Court affirmed the lower court's decision refusing to enjoin state proceedings. ${ }^{224}$ The plaintiff sought the injunction on the theory that the broad prohibition of $\S 2283$ against interference in state proceedings should yield because Congress had preempted the field by legislation. ${ }^{225}$ The Court upheld the lower court's decision:

The assumption upon which the argument proceeds is that federal rights will not be adequately protected in the state courts, and the "gap" complained of is impatience with the appellate process if state courts go wrong. But during more than half of our history Congress, in establishing the jurisdiction of the lower federal courts, in the main relied on the adequacy of the state judicial systems to enforce federal rights, subject to review by this Court.... We cannot assume that this confidence has been misplaced. ${ }^{226}$

Although the source of the state obligation to give full credit to federal judgments remains somewhat unsettled, ${ }^{227}$ the Court in several

${ }^{291}$ Tafflin, 493 U.S. at 458.

2292428 U.S. 465 (1976).

${ }^{223}$ Id. at $493-94$ n.35.

224348 U.S. 511 (1954) (finding that the federal district court is denied power to enjoin state court proceedings under 28 U.S.C. $\$ 2283$ ).

${ }_{225}$ See id. at 515 (stating that the prohibition in $\$ 2283$ against granting an injunction to stay state court proceedings can be held applicable whenever the party applying for an injunction claims that the state court is without jurisdiction over the subject matter because it has been pre-empted by Congress).

${ }^{226} \mathrm{Id}$. at 518.

297 No constitutional or statutory provision compels state courts to give preclusive effect to federal judgments. To this day, Congress has never legislated an obligation for state courts to give full faith and credit to federal judgments. The Full Faith and Credit Clause of the Constitution, Article IV, Section 1, commands that state courts give credit to all sister-state court judgments. U.S. CONST. art. IV, $\S 1$. This obligation was expanded when Congress enacted the Full Faith and Credit Act, now 28 U.S.C. $\$ 1738$, so that all federal courts must accord full faith and credit to state judgments. 28 U.S.C. $\$ 1738$ (1994). Literally read, however, $\$ 1738$ does not speak to the obligation of state courts to respect federal decrees. Although neither the constitutional 
key decisions has ruled that federal courts must not intervene once a state court makes a preclusion determination and such determination is finalized under that state's law. In Parsons Steel, Inc. v. First Alabama Bank, several plaintiffs sued the First Alabama Bank in separate actions in state and federal court. ${ }^{228}$ The federal court case proceeded to trial

provision nor statute expressly refer to the obligation by state courts to honor federal decrees, in several early cases the Supreme Court concluded that states owed full faith and credit to federal judgments. See, e.g., Embry v. Palmer, 107 U.S. 3, 9-10 (1883) (noting that "the judgments of the courts of the United States have invariably been recognized as upon the same footing ... with domestic judgments of the states, wherever rendered and wherever sought to be enforced"); Dupasseur v. Rochereau, 88 U.S. (21 Wall.) 130, 135 (1874) (noting that "[i]f by the laws of the State a judgment like that rendered by the Circuit Court would have had binding effect... if it had been rendered in a State court, then it should have the same effect, being rendered by the Circuit Court"). These decisions have been criticized for misreading the Full Faith and Credit Clause and $\$ 1738$, though it is noteworthy that they have not been directly overruled. See HART \& WECHSIER, supra note 14, at 1473 (observing that these authorities have caused "confusion as to what makes the preclusive effects of federal judgments in state cases a federal matter").

Beyond these suspect cases, several distinguished commentators have posited that state courts are bound by federal law to give credit to federal judgments. In his influential article, Federalized Res Judicata, Professor Ronan Degnan argued that state courts were bound to give credit to federal judgments because once Congress exercised the constitutional power to create the lower federal courts, it necessarily follows that those courts must be able to render decisions with binding effect. Ronan E. Degnan, Federalized Res Judicata, 85 YAIE L.J. 741 (1976). According to Degnan,

To decide a case or controversy implies some binding effect. A judgment or decree that lacked finality would constitute something other than an exercise of the judicial power .... [Therefore,] it seems inappropriate that some other sovereignty-the states-should have ultimate authority to determine what binding effect the judgment has and on whom.

Id. at 768-69.

Professor Charles Alan Wright has similarly observed that if it was uncertain whether federal judgments would be given preclusive effect in state courts, then federal courts' ability to exercise judgment would be circumscribed. See CHARLES ALAN WRIGHT, LAW OF FEDERAL COURTS 736-37 (5th ed. 1994) (arguing that "[p]roceedings that do not have at least the potential effect of precluding later relitigation of the same claims and issues would constitute something other than the exercise of judicial power"). Whether grounded in the Full Faith and Credit Act, the Supremacy Clause, or federal common law, the state obligation to give credit to federal judgments is largely settled. See Burbank, supra note 212, at 738-39 (observing that "traditional federal common law analysis and analysis under the Rules of Decision Act support the accepted (but unreasoned) conclusion that uniform federal preclusion law governs the interjurisdictional effects of federal judicial proceedings adjudicating matters of federal substantive law"); see also Erichson, supra note 212, at 986 (commenting that "[n]o doubt each state tribunal, left to its own devices, ordinarily would choose to give due effect to federal judgments").

${ }^{223} 474$ U.S. 518 (1986). 
first and the court rendered judgment for the bank. ${ }^{229}$ The bank then asked the state court to dismiss the state action on the grounds that the federal judgment was res judicata of all claims asserted by plaintiffs in the state action. ${ }^{230}$ The state court rejected this res judicata argument, ruling the state claims were not precluded by the prior federal judgment, and subsequently entered a verdict for the plaintiffs. ${ }^{231}$

Unsuccessful in their bid before the state court judge to halt the state court proceedings, defendants then returned to the federal district court and asked the federal judge to enjoin further state court proceedings. ${ }^{232}$ The federal court agreed with the defendants and granted injunctive relief, preventing plaintiffs from pursuing their state court suit, and a majority of the court of appeals affirmed. ${ }^{233} \mathrm{Ac}-$ cording to the court of appeals, the plaintiffs could have brought their state claims as pendent claims in the federal court proceeding. ${ }^{234}$ Thus, res judicata should have barred plaintiffs' state action after the entry of the federal judgment. ${ }^{235}$ The court of appeals then ruled that an injunction could be issued pursuant to the relitigation exception to the Anti-Injunction Act as "the relitigation exception empowers a federal court to be the final adjudicator as to the res judicata effects of its prior judgments on a subsequent state action. ${ }^{236}$

In an opinion for a unanimous court, Justice Rehnquist reversed. $^{237}$ Citing its earlier decision in Marrese $v$. American Academy of Orthopaedic Surgeons, ${ }^{238}$ the Court ruled that the court of appeals "gave

${ }^{229}$ See $i d$. at 520 (noting that while the federal jury returned a verdict in the plaintiffs' favor, the district court judge granted a judgment n.o.v. to the bank).

${ }^{230} \mathrm{See} i d$. (indicating that the bank pleaded the defenses of res judicata and collateral estoppel in the state action based on the federal judgment).

${ }^{231}$ See id. (stating that the bank, the prevailing party in the federal suit, lost its argument in state court on the res judicata effect of the federal judgment).

${ }^{232}$ See id. at 520-21 (noting that the bank filed an injunctive action in the same federal district court "that had previously entered judgment in the bank's favor").

${ }^{235}$ See id. at 521 (stating the district court's finding that the federal suit and the state action were based on the same factual allegations and requested the same damages).

${ }^{234}$ See First Alabama Bank v. Parsons Steel, Inc., 747 F.2d 1367, 1373-74 (11th Cir. 1984) (finding that the district court was correct in finding that the plaintiffs could have brought the fraud and UCC claims in federal court), rev'd, 474 U.S. 518 (1986).

${ }^{235}$ See id. at 1381 (affirming the district court's decision that the state court proceedings were barred by res judicata).

${ }^{236} I d$. at 1376.

${ }^{237}$ See Parsons Steel, 474 U.S. at 526 (reversing the court of appeals and remanding the case for further proceedings).

29340 U.S. 373 (1985). 
unwarrantedly short shrift to the important values of federalism and comity embodied in the Full Faith and Credit Act. ${ }^{\text {,239 }}$ In Marrese, the Court had affirmed its prior holding in Migra v. Warren City School District Board of Education ${ }^{240}$ that the Full Faith and Credit Act requires a federal court to give the same preclusive effect to a state court judgment as another court of that state would give. ${ }^{241}$ Relying on these earlier precedents, the Court in Parsons Steel held that the court of appeals "erred by refusing to consider the possible preclusive effect, under Alabama law, of the state-court judgment. ${ }^{242}$ The Court refused to find that the relitigation exception to $\$ 2283$ acted to trump the command of $\S 1738 .{ }^{243}$ Instead, the Court observed that $\S 1738$ and $\S 2283$ could be read together

simply by limiting the relitigation exception of the Anti-Injunction Act to those situations in which the state court has not yet ruled on the merits of the res judicata issue. Once the state court has finally rejected a claim of res judicata, then the Full Faith and Credit Act becomes applicable and federal courts must turn to state law to determine the preclusive effect of the state court's decision. ${ }^{244}$

In Parsons Steel, the Court emphasized that the Full Faith and Credit Act compelled federal deference to the state court, even if the cost was allowing an erroneous ruling on the preclusive effect of a prior federal judgment to stand. ${ }^{245}$ The Court's decision in Parsons Steel reflects some of the difficulties of trying to draw bright-line rules to govern when federal intervention in state court proceedings is warranted. One difficulty with the standard articulated is that it may encourage parties to bypass the state court by going immediately to federal court for injunctive relief. Professor Diane Wood has remarked that two consequences of the Court's decision are to encourage evasion of state proceedings and to place the federal courts in the position of second-guessing state court determinations about the effect of federal court judgments. As she has observed, "[t]he first conse-

${ }^{239}$ Parsons Steeh 474 U.S. at 523.

240465 U.S. 75 (1984).

241 Marrese, 470 U.S. at 384.

${ }^{212}$ Parsons Steel, 474 U.S. at 525.

${ }^{243}$ See id. at 523-24 (noting that the court of appeals found in $\$ 2283$ an implied repeal of $\S 1738$, and reiterating that such repeals are disfavored).

${ }^{24} I d$ at 524 .

${ }^{245}$ See id. at 525 (stating that "[c]hallenges to the correctness of a state court's determination as to the conclusive effect of a federal judgment must be pursued by way of appeal through the state-court system and certiorari from this Court"). 
quence totally ignores the comity and federalism basis of the AntiInjunction Act, and the second comes close to violating the principles underlying the Rooker-Feldman doctrine. ${ }^{\text {246 }}$ In this sense, the decision in Parsons Steel is anomalous because it permits-indeed, even encourages-litigants to seek injunctive relief before exhausting all other available remedies. This is contrary to the traditional principle that equitable relief is generally only available after all other legal remedies have been exhausted, ${ }^{247}$ and to the long-recognized rule that resort to the All Writs Act is appropriate only if no adequate remedy at law exists. ${ }^{248}$

In its most recent discussion of the role of state courts in determining the preclusive effect of prior federal judgments, the Court came down resoundingly in favor of deference to the state courts to determine the preclusive effect of prior federal judgments. ${ }^{249}$ As noted earlier, ${ }^{250}$ the question in Rivet $v$. Regions Bank was whether a case was properly removed to federal court from Louisiana state court on the grounds that the plaintiffs' state cause of action was completely precluded by a federal bankruptcy court's prior judgment. ${ }^{251}$ Relying on Federated Department Stores, Inc. v. Moitie, ${ }^{252}$ the Fifth Circuit in Rivet approved the district court's denial of the plaintiffs' motion to remand. ${ }^{253}$ The Fifth Circuit upheld removal on the grounds that removal was permissible under Moitie "where a plaintiff files a state cause of action completely precluded by a prior federal judgment on a question of federal law. ${ }^{254}$ In its decision, the Supreme Court reversed the Fifth Circuit, clarifying that "Moitie did not create a preclusion excep-

${ }^{246}$ Wood, supra note 207, at 306 . For a good description of the Rooker-Feldman doctrine, see Symposium, The Rooker-Feldman Doctrine, 74 NOTRE DAME L. REV. 1081 (1999).

${ }^{247}$ But see infra text accompanying notes 308-16 (discussing Professor Douglas Laycock's examination of the "irreparable injury rule").

${ }^{248}$ See supra note 133 and accompanying text (discussing the proper invocation of the All Writs Act).

249 See Rivet v. Regions Bank, 522 U.S. 470, 472 (1998) (holding that removal based on a claim of preclusion by reason of a prior federal judgment is improper).

${ }^{250}$ See supra text accompanying notes 80-88 (discussing how Rivet clarified the Supreme Court's decision in Moitie).

251522 U.S. 470 (1998).

${ }^{252} 452$ U.S. 394 (1981), limited by Rivet v. Regions Bank, 522 U.S. 470 (1998).

${ }^{253}$ See Rivet v. Regions Bank, 108 F.3d 576, 586 (5th Cir. 1997) (finding that the state action was precluded by prior bankruptcy court orders), rev'd, 522 U.S. 470 (1998).

${ }^{254}$ Id. (quoting Carpenter v. Wichita Falls Indep. Sch. Dist., 44 F.3d 362, 370 (5th Cir. 1995)). 
tion to the rule, fundamental under currently governing legislation, that a defendant cannot remove on the basis of a federal defense. ${ }^{.255}$

Thus, Rivet stands for the proposition that in preclusion cases, federal courts are usually bound to defer to state court judges to decide federal law issues. Yet, just as Parsons Steel may be charged with being too rigid, Rivet may be criticized for lending greater confusion and uncertainty to the fundamental problem of where to draw the line between deference and intervention. In the same paragraph which emphasizes the importance of deference to the state court in federal claim prechusion cases, the Rivet opinion also notes that federal courts may enjoin state court proceedings under the relitigation exception. ${ }^{256}$ The Eighth Circuit has already interpreted this footnote as indicating that the Supreme Court considers injunctive relief to be one of several available alternatives for the federal court to consider. ${ }^{257}$ The Eighth Circuit upheld removal in Metropolitan Council II by commenting that this reference in Rivet merely "points out another procedural option, but we do not read footnote three to rule out the one we approved.. ${ }^{258}$ The Rivet footnote adds uncertainty to this area of the law because it suggests that deference to the state court is onebut not the only - option available to a federal court in a federal claim preclusion case. It could be cogently argued, therefore, that rather than mandating deference, Rivet merely recognizes deference as one of several options available to a federal court in a federal claim preclusion case.

It would have been better if the Court had elaborated what it meant by saying a court could resort to the relitigation exception of the Anti-Injunction Act. Presumably, the Court meant that an injunction would be appropriate pursuant to the general power possessed by the court under the All Writs Act, so long as injunctive relief was not barred by the Anti-Injunction Act. Nonetheless, the Eighth Circuit's interpretation of this footnote in Rivet to support removal under the All Writs Act is almost certainly incorrect. Two shortcomings in the court's reasoning are apparent. First, even if the Eighth Circuit is

${ }^{255}$ Rivet, 522 U.S. at 478.

${ }^{256}$ Rivet, 522 U.S. at 478 n.3 (stating that "under the relitigation exception to the Anti-Injunction Act, a federal court may enjoin state court proceedings if necessary ... to protect or effectuate its judgments").

${ }^{257}$ See Metropolitan Council II, 144 F.3d 1168, 1172 (8th Cir. 1998) (finding that the prior decision to remove the state claim to federal court under the All Writs Act was not at odds with the Court's decision in Rivet and reinstating the earlier decision).

258 Id. at 1172. 
right in interpreting Rivet's third footnote to mean that federal courts have the equal choice of two alternatives, those alternatives are between enjoining the state court action, on the one hand, or deferring to the state court judge to adjudicate the federal law issues implicated in a subsequent state case, on the other. Removal of the state court action under the All Writs Act is not a third alternative; certainly nothing in Rivet supports the Eighth Circuit's approval of removal of a non-Article III case pursuant to $\S 1651$ (a).

The second, and perhaps more fundamental, shortcoming of the Eighth Circuit's reasoning in Metropolitan Council II is that it assumes federal courts in most cases may decide equally between deference to or interference with state court proceedings. This is not the most plausible reading of the Supreme Court's decision. If Rivet does not mean that federal claim preclusion defenses should usually be raised in the state court, then it is difficult to ascribe any meaningful significance to the Court's decision. If a defendant is barred from coming into federal court by removing the state action on the basis of federal claim preclusion, then she should not be able to reach the federal forum by the alternative path of filing an ancillary jurisdiction suit to enjoin the state court proceeding. The contrary result would eviscerate the holding of the Rivet case. Moreover, the well-pleaded complaint rule, which the holding in Rivet affirmed, ${ }^{259}$ is a judicially-created doctrine, not a legislative mandate. ${ }^{260}$ That the well-pleaded complaint rule was not narrowed or abandoned, therefore, lends support to the conclusion that Rivet acknowledges the capability of state courts to handle most Type II cases without interference by the lower federal courts. ${ }^{261}$

The shortcomings of the Court's opinion in Rivet, and the problems attendant to Parsons Steel are really different sides of the same

${ }^{259}$ See Rivet, 522 U.S. at 475 (upholding the well-pleaded complaint rule).

${ }^{260}$ See Louisville \& Nashville R.R. v. Mottley, 211 U.S. 149, 154 (1908) (ruling that "a suit arises under the Constitution and laws of the United States only when the plaintiff's statement of his own cause of action shows that it is based upon those laws or that Constitution" and citing a long line of authorities in support of the well-pleaded complaint rule, starting with Metcalf $v$. City of Watertown, 128 U.S. 586 (1888)); see also Donald L. Doernberg, There's No Reason for It; It's Just Our Policy: Why the Well-Pleaded Complaint Rule Sabotages the Purposes of Federal Question Jurisdiction, 38 HASTINGS L.J. 597, 59899 (1987) (commenting that "Mottley is the case most commonly cited" for the wellpleaded complaint rule and arguing that the rule ought to be abandoned).

${ }^{261}$ See Rivet, 522 U.S. at 478 (concluding that claim preclusion by reason of a prior federal judgment is a defense that provides no basis for removal and that is properly made in state court proceedings). 
coin. Both reflect the difficulties of trying to draw the line between federal intervention and deference to sovereign state court proceedings. While these decisions may be criticized for their internal inconsistencies, they are consistent with other precedents in which the Court has outlined a broad mandate for deference to state courts. In Chick Kam Choo v. Exxon Corp., the plaintiff had initially filed suit in federal court asserting claims under federal statutory law, general federal maritime law, and under the Texas wrongful death statute. ${ }^{262}$ The district court granted summary judgment on the federal statutory claims, as well as on the general federal maritime law claims, and dismissed the case on forum non conveniens grounds. ${ }^{263}$ After the plaintiff subsequently filed suit in state court alleging claims under Texas and Singapore law, defendants returned to federal court, successfully obtaining an injunction prohibiting plaintiff from prosecuting her action in this country. ${ }^{264}$ A divided panel of the Fifth Circuit held that "the injunction ... fell within the 'relitigation' exception to the [AntiInjunction] Act."265 Reversing the Fifth Circuit, the Supreme Court ruled that the injunction was only proper as to any claims which the district court actually decided. ${ }^{266}$ Thus, on remand, if the plaintiff continued to assert claims under Texas law, it would be appropriate for the federal court to consider whether to enjoin those particular claims because the federal court had actually decided that "Singapore law must control [the plaintiff's] lawsuit. ${ }^{267}$ Federal injunctive relief was unavailable, however, to enjoin the plaintiff from litigating before the state court the question of whether federal maritime law preempted state forum non conveniens law, because that issue was not "actually litigated and decided by the District Court." ${ }^{263}$

${ }^{262}$ See 486 U.S. 140, 142 (1988) (noting that the petitioner presented claims under the Jones Act, the Death on the High Seas Act, the general maritime law of the United States, and the Texas wrongful death statute).

26s See id. at 143 (stating that the district court, after disposing of the federal statutory claims and general federal maritime law claims, conditionally dismissed the case on forum non conveniens grounds provided that respondents submitted to the jurisdiction of Singapore courts).

${ }^{264}$ See id. at 144 (quoting the district court's decision to enjoin the petitioner from commencing any action arising out of the alleged wrongful death of her husband).

${ }_{265}$ Id.

${ }^{266}$ See id. at 148 (finding that an essential prerequisite for applying the relitigation exception is that the claims or issues targeted by the federal injunction must be claims or issues actually decided by a federal court).

267 Id. at 150.

26s Id at 149. 
Other Supreme Court and appellate court decisions similarly have established that "a claim of federal preemption-even one which is unmistakably clear-is not within any of the [recognized] exceptions" to the Anti-Injunction Act. ${ }^{269}$ Indeed, the possibility that a federal statute may entirely preempt the field and deprive the state court of jurisdiction is still considered an insufficient basis to justify federal intervention. ${ }^{270}$ Moreover, as a recent Eleventh Circuit decision demonstrates, the doctrine of res judicata is a more appropriate method than issuance of injunctive relief for protecting a prior judgment. ${ }^{271}$ The court's specific holding in Weaver v. Florida Power $\mathcal{E}^{2}$ Light $C o$. was that the district court abused its discretion in enjoining an arbitration proceeding because the defenses of res judicata and waiver were available to the defendant to assert in the arbitration and, therefore, the defendant had an adequate remedy at law. ${ }^{272}$ The court's reasoning reflects the view that injunctions against parallel litigation are generally not appropriate and that the preclusion doctrines typically serve to protect prior judgments adequately. Consideration of these authorities suggests, then, that $\S 1651$ (a) removal jurisdiction conflicts with doctrinal law on preclusion cases. There may be instances in which a state court will not be capable of making the preclusion determinations, or where there are other reasons to suspect that the federal judgment will not be adequately protected. In these circumstances, it may be appropriate for a federal court to intervene, not by removing the state court action pursuant to the All Writs Act, but by using the statute to support the issuance of injunctive relief. The power and limitations of a federal court to issue such injunctive relief against state proceedings are examined next.

${ }^{269}$ Texas Employers' Ins. Ass'n v. Jackson, 862 F.2d 491, 498 (5th Cir. 1988) (describing federal claims that are not sufficient to authorize an injunction of state court proceedings); see also Sternlight, supra note 207, at 163 \& n.300 (listing appellate cases supporting the proposition that "the mere fact that federal issues are presented in a state case, even combined with the fact that those federal issues are preemptive, does not justify a federal court in enjoining the state court's consideration of those issues").

${ }_{270}$ For an example of this principle, in which the National Labor Relations Act deprived the state court of jurisdiction, see Amalgamated Clothing Workers $v$. Richman Bros. Co., 348 U.S. 511, 515 (1955) (refusing to accept the argument in support of federal injunctive relief "that $\$ 2283$ does not apply whenever the moving party in the District Court alleges that the state court is "wholly without jurisdiction over the subject matter, having invaded a field preempted by Congress'" and, therefore, finding no basis for ignoring $\$ 2283$ 's prohibition (citation omitted)).

271 See Weaver v. Florida Power \& Light Co., 172 F.3d 771, 773 (11th Cir. 1999).

${ }^{272} I d$. 


\section{B. Anti-Injunction Act, 28 U.S.C. § 2283}

Under the Anti-Injunction Act, a federal court may not enjoin state proceedings unless one of the express statutory exceptions is satisfied. ${ }^{273}$ Injunctive relief under $\S 1651$ (a) is also limited by common law prerequisites for issuance of injunctive relief-a showing of irreparable harm and lack of an adequate remedy at law. ${ }^{274}$ The Act represents a long-standing legislative directive against interference in state court litigation. The exceptions to the Act, however, demonstrate that in some circumstances a federal issue is compelling enough, and the concern over state court adjudication is great enough, to justify federal intervention. These two antithetical principles often clash, resulting in continuing tension and inconsistent decisions on the extent to which the Act proscribes federal interference with state court proceedings.

Enacted in 1793, the Anti-Injunction Act was promulgated against a backdrop of acute concern and debate over the potential friction deriving from having state and federal judicial systems with concurrent jurisdiction. It is a matter of historical record that the drafters intended for the Act to play a central role in maintaining harmony between federal-state relations. In Atlantic Coast Line Railroad Co. $v$. Brotherhood of Locomotive Engineers, ${ }^{275}$ Justice Black discussed the "background and policy that led Congress to pass the [A]nti-[I]njunction Statute in 1793. ${ }^{276}$ "When this Nation was established by the Constitution," Black observed, "each State surrendered only a part of its sovereign power to the national government. But those powers that were not surrendered were retained by the States .... One of the reserved powers was the maintenance of state judicial systems for the decision of legal controversies." that separate federal courts were unnecessary and that the state courts could be entrusted to protect both state and federal rights," while

${ }^{273}$ See 28 U.S.C. $\$ 2283$ (1994) ("A court of the United States may not grant an injunction to stay proceedings in a State court except as expressly authorized by Act of Congress, or where necessary in aid of its jurisdiction, or to protect or effectuate its judgments.").

${ }^{774}$ See, e.g., Brittingham v. Commissioner, 451 F.2d 315, 318 (5th Cir. 1971) (refusing to enjoin a tax court pursuant to $\S 1651$ because, inter alia, "an injunction should be granted only upon a showing of irreparable harm and lack of an adequate remedy at law").

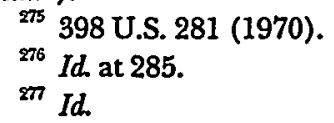


others favored "a complete system" of federal courts to handle federal legal matters. ${ }^{278}$

Black, previously a member of the Senate, correctly discerned the legislative division over the role of the federal courts in the First Congress. During the debates on enactment of the Judiciary Act of 1789, legislators wrestled over the meaning of the constitutional provisions relating to the judiciary. In particular, legislators debated whether a system of lower federal courts should exist and, if so, how much power to bestow on them. ${ }^{279}$ Ultimately, as Justice Black recounts, the First Congress resolved these various positions by reaching a compromise:

While the lower federal courts were given certain powers in the 1789 Act, they were not given any power to review directly cases from state courts, and they have not been given such powers since that time.... Thus from the beginning we have had in this country two essentially separate legal systems. Each system proceeds independently of the other with ultimate review in this Court of the federal questions raised in either system.

A system of concurrent jurisdiction still entailed the risk of friction between state and federal courts, and during the debates over the First Judiciary Act, many in Congress voiced concern regarding the dangers of the two sovereign systems colliding. As Justice Black remarked in his majority opinion in Atlantic Coast Line, "this dual system could not function if state and federal courts were free to fight each other for

${ }^{278}$ Id.

${ }^{279}$ Representative Livermore, for instance, who opposed the creation of federal courts with broad powers, argued forcefully for Congress to withhold establishing a system of inferior federal tribunals:

There is already in each State a system of jurisprudence, congenial to the wishes of its citizens. I never heard it complained that justice was not distributed with an equal hand in all of them; I believe it is so, and the people think it so. We had better then continue them than introduce a system replete with expense, and altogether unnecessary.

1 ANNALS OF CONGRESS 813-14 (Joseph Gales ed., 1789). Supporters of the establishment of federal courts with broad judicial powers countered that inferior federal courts were both mandated by the Constitution and necessary to ensure that a forum existed for the fair adjudication of matters of federal law. One supporter, Representative Smith of South Carolina, remarked:

Here [in Article III] is no discretion, then, in Congress to vest the judicial power of the United States in any other tribunal than in the Supreme Court and the inferior courts of the United States.... The district court is necessary, if we intend to adhere to the constitution, and to carry the Government into effect.

Id. at 831-32.

${ }^{280}$ Atlantic Coast Line, 398 U.S. at 286. 
control of a particular case. ${ }^{281}$ Into this gap came the Anti-Injunction Act, which states: "Thus, in order to make the dual system work . . ., it was necessary to work out lines of demarcation between the two systems.... The 1793 [A]nti-[I]njunction Act was at least in part a response to these pressures. ${ }^{282}$ By prohibiting "frequent federal court intervention" into state judicial proceedings, "the Act forestalls 'the inevitable friction between the state and federal courts that ensues from the injunction of state judicial proceedings by a federal court.',283

As originally enacted, the Anti-Injunction Act was an absolute prohibition against enjoining state proceedings. ${ }^{284}$ Over time, exceptions were made to the complete statutory ban, ${ }^{285}$ testimony to a reluctant but palpable recognition by courts and legislators that federal interference with state proceedings may sometimes be unavoidable. ${ }^{286}$ Exceptions to the broad principle of non-interference, however, were few. In 1941, Justice Frankfurter admonished that "apart from Congressional authorization, only one 'exception' has been imbedded in the [Anti-Injunction Act] by judicial construction, to wit, the res cases. ${ }^{\text {"287 }}$ In 1948, to counter the Court's decision in Toucey, Congress revised the Anti-Injunction Act expressly to include the relitigation

${ }^{231}$ Id.

${ }^{232}$ Id. In a later opinion, the Court described $\$ 2283$ as "a necessary concomitant of the Framers' decision to authorize, and Congress' decision to implement, a dual system of federal and state courts. It represents Congress' considered judgment as to how to balance the tensions inherent in such a system." Chick Kam Choo v. Exxon Corp., 486 U.S. 140, 146 (1988).

${ }^{233}$ Chick Kam Choo, 486 U.S. at 146 (quoting Vendo Co. v. Lektro-Vend Corp., 433 U.S. 623,630 (1977)) .

${ }^{284}$ Section 5 of the Act of March 2, 1793 originally provided that "writs of ne exeat and of injunction may be granted by any judge of the supreme court... but no... writ of injunction [shall] be granted to stay proceedings in any court of a state." Act of March 2, 1793, ch. 22, § 5, 1 Stat. 334, 334-35.

${ }_{205}$ In 1874, for example, Congress added an exception for cases where an injunction was issued pursuant to a federal bankruptcy proceeding. Rev. Stat. of 1874, ch. 12, $\S 720,18$ Stat. 134, 137. This exception was then incorporated into the 1911 Judicial Code. See Act of March 3, 1911, ch. 231, § 265, 36 Stat. 1087, 1162 ("The writ of injunction shall not be granted . . . except in cases where such injunction may be authorized by any law relating to proceedings in bankruptcy.").

${ }^{286}$ See Amalgamated Sugar Co. v. NL Indus., Inc., 825 F.2d 634, 639 (2d Cir. 1987) ("While the Anti-Injunction Act is designed to avoid disharmony between federal and state systems, the exception in $\$ 2283$ reflects congressional recognition that injunctions may sometimes be necessary in order to avoid that disharmony.").

${ }^{237}$ Toucey v. New York Life Ins. Co., 314 U.S. 118, 139 (1941), superseded by 28 U.S.C. $§ 2283$ (1994). 
exception, the most significant of the three current exceptions. ${ }^{288}$ Also in 1948, the "necessary in aid of its jurisdiction" exception was added to conform the Anti-Injunction Act to the All Writs Act. ${ }^{289}$ To day, there are only three recognized exceptions to the Anti-Injunction Act and unless one is satisfied, the Act is held to be an absolute bar against federal interference in enjoining state proceedings. ${ }^{290}$

In Vendo Co. v. Lektro-Vend Corp., ${ }^{291}$ the Court observed that the initial presumption under the Anti-Injunction Act must be that "any doubts as to the propriety of a federal injunction against state court proceedings should be resolved in favor of permitting the state courts to proceed in an orderly fashion to finally determine the controversy." ${ }^{292}$ Relaxing the strict standards, the Court cautioned, would result in "judicial improvisation." tion 16 of the Clayton Act was not an express exception to the AntiInjunction Act. To hold otherwise, the Court ruled, would mean that "[t]he Anti-Injunction Act, a fixture in federal law since 1793, would then be a virtual dead letter whenever the plaintiff seeks an injunction under a federal injunctive statute. Whether or not the state proceeding could be enjoined would rest solely upon the traditional principles of equity and comity. ${ }^{294}$ Such judicially-made doctrines of equity were not recognized grounds for avoiding the Anti-Injunction Act, however:

${ }^{288}$ See 28 U.S.C. $\$ 2283$ (1994) (stating in the Historical Notes that "the revised section restores the basic law as generally understood and interpreted prior to the Toucey decision").

${ }^{289}$ See id. (explaining that this provision "[made] clear the recognized power of the Federal courts to stay proceedings in State cases removed to the district courts").

${ }^{290}$ See Chick Kam Choo v. Exxon Corp., 486 U.S. 140, 146 (1988) (emphasizing that the exceptions to $\S 2283$ are "not [to] be enlarged by loose statutory construction" and that "an injunction staying state proceedings is proper only if it falls within one of the statutory exceptions" (citation omitted)); see also Atlantic Coast Line R.R. v. Brotherhood of Locomotive Eng'rs, 398 U.S. 281, 286 (1970) (remarking that the "Act is an absolute prohibition against enjoining state court proceedings, unless the injunction falls within one of [the] three specifically defined exceptions"). But see Wood, supra note 207, at 289-90 (observing that, notwithstanding the existence of the three exceptions, "the courts have continued to treat the statutory language somewhat like silly putty, stretching and squashing it in an effort to use anti-suit injunctions against state court proceedings when circumstances seemed to justify them").

${ }^{291} 433$ U.S. 623 (1977).

${ }_{292} I d$ at 630 (quoting Atlantic Coast Line, 398 U.S. at 297).

${ }^{299}$ Id. at 631 (quoting Amalgamated Clothing Workers v. Richman Bros. Co., 348 U.S. $511,514(1955))$.

Id. at 639 . 
[T] he prohibitions of $\$ 2283$ exist separate and apart from these traditional principles [of equity and comity], and we cannot read the "intended scope" language as rendering this specific and longstanding statutory provision inoperative simply because important federal policies are fostered by the statute under which the injunction is sought. Congress itself has found that these policies, in the ordinary case, must give way.....

The presence of competing policy objectives within the same statute has created an internal tension in the Anti-Injunction Act, with the broad, general language of the Act pulling in one direction and the later-enacted exceptions pulling the other way. Professor Wood has concluded from her own study that "[t]he Anti-Injunction Act is badly in need of attention... . The Act still suffers from 'dense clouds of ambiguity,' and still might fairly be called the 'most obscure of jurisdictional statutes." ${ }^{296}$ Concurring with Professor Currie's earlier recommendation, Wood urged a revision of the Act to "abandon the effort to spell out the circumstances under which state proceedings may be enjoined, and to rewrite the statute to express the general policies on which it rests. ${ }^{297}$

Proponents of $\S 1651$ (a) removal jurisdiction might posit that the Anti-Injunction Act is simply inapplicable to a case removed under the All Writs Act since removal is a party-initiated procedure, while the Anti-Injunction Act is directed to proscribe courts from interfering in state proceedings. This necessarily invites a comparison of a court's power to enjoin with its authority to uphold removal of a state case. If a federal court issues an injunction suspending a state court suit, has it interfered any more or less than if it would have denied remand to a case removed from state court? While some courts have sidestepped this question, ${ }^{298}$ at least theoretically there may be little to distinguish the power to enjoin from the power to uphold removal, because both suspend further state proceedings. ${ }^{299}$ Still, this broad comparison of

${ }^{295}$ Id.

${ }^{296}$ Wood, supra note 207, at 320 (quoting David P. Currie, The Federal Courts and the American Law Institute, pt. 2, 36 U. CFI. L. REV. 268, 322 (1969)).

${ }^{297}$ Wood, supra note 207 , at 320.

${ }^{203}$ See Agent Orange II, 996 F.2d 1425, 1432 (2d Cir. 1993) (rejecting the argument that removal of suit violated $\S 2283$, but noting that its decision was made by "[a]ssuming without deciding that removal of a case from state court to federal court is sufficiently akin to an injunction to come within the Act's ambit").

${ }^{299}$ The congressional grant of removal power to the federal courts is generally regarded as falling within the "expressly authorized" exception of $\S 2283$ for Acts of Congress. SeeWood, supra note 207, at 299 (placing removal cases within this category 
the two powers is deceiving. It fails to recognize that the AntiInjunction Act, as well as equitable principles, severely restrict the circumstances in which a federal court may enjoin state proceedings. Yet, in the recent rush to remove cases under the All Writs Act, an illdefined measure has been substituted for the stringent standards embodied in the Anti-Injunction Act. The "exceptional circumstances" standard, employed by courts in approving $§ 1651$ (a) removal jurisdiction, has supplanted the express exceptions of the Anti-Injunction Act. $^{300}$ A unique factual situation may constitute "exceptional circumstances" even if the same facts would not qualify for one of the express exceptions to the Anti-Injunction Act. This disparity had led to the anomalous result that an action removed from state court may withstand an attempt at remand even if a request for injunctive relief would have been denied under the Anti-Injunction Act. Yet, numerous courts have also found that $\S 1651$ (a) is to be read in harmony with and subject to $\S 2283$ and that the All Writs Act was meant to be employed only to support the issuance of injunctive relief when the injunction is permissible under the Anti-Injunction Act. ${ }^{301}$ Thus, a consequence of the expanded use of $\S 1651$ (a) to justify removal jurisdiction is that the balance between state and federal rights, which should be a concern of the highest order, ${ }^{302}$ has been altered. In this manner, the "exceptional circumstances" standard further augments the danger of "judicial improvisation" against which Vendo cau-

with some reservations, but noting that "they do not fit elsewhere any better"). Because removal under $\S 1651$ (a) has not been expressly authorized by Congress, however, these authorities should not be considered controlling. The question thus remains as to whether a case removed by $\S 1651$ (a) may implicate $\$ 2283$.

${ }^{300}$ Some courts which have approved removal under the All Writs Act have determined that the removal satisfies the relitigation exception to the Anti Injunction Act. In Agent Orange II, for instance, the Second Circuit found that both the "necessary in aid of its jurisdiction" and the "relitigation exception" were satisfied by the threat of the subsequent state actions. See Agent Orange II, 996 F.2d at 1432 (noting that "the district court's removal was 'necessary in aid of its jurisdiction" and "to protect or effectuate' the district court's Agent Orange Ijudgement").

${ }^{301}$ See, e.g., Atlantic Coast Demolition and Recycling, Inc. v. Board of Chosen Freeholders, 988 F. Supp. 486, 491 (D.N.J. 1997) (remarking that $\$ \$ 2283$ and 1651 "are closely related" and should be construed together); Olin Corp. v. Insurance Co. of North America, 807 F. Supp. 1143, 1152 (S.D.N.Y. 1992) (concurring in the conclusion that "section 2283 must be construed in connection with section 1651" (quoting Baker v. Gotz, 415 F. Supp. 1243, 1247 (D. Del. 1976)).

${ }^{302}$ See Railroad Comm'n v. Pullman Co., 312 U.S. 496, 500 (1941) (noting that "[f] ew public interests have a higher claim upon the discretion of a federal chancellor than the avoidance of needless friction with state policies"). 
tioned. ${ }^{303}$

\section{Drawing Lines of Demarcation Between Deference and Interference}

No definitive bright-line rule can guide courts and litigants in determining when federal intervention is appropriate, and corralling all of the circumstances in which injunctive relief under the All Writs Act would be warranted is not possible. Nevertheless, it is instructive to study the circumstances in which the All Writs Act has been approved as removal authority. I have attempted to show that distinguishing between different kinds of cases is important because the policy reasons for or against federal intervention will largely turn on the nature of the underlying circumstances and issues in the case. Where a state court is only to determine the preclusive effects of a prior federal judgment, the threat to federal interests is generally perceived as less severe than in cases in which the state court determination may affect a federal judgment in non-preclusive ways. Parsons Steel and, more recently, Rivet, affirm that in most Type II cases it is appropriate for the federal courts to defer to the state courts to determine the preclusive effects of a prior federal judgment; these decisions are grounded in a recognition of the competency of state courts to decide federal preclusion questions.

In these and other decisions, the Court has articulated a broad mandate for deference to the state court in Type II cases, and has recognized the competence of state courts to adjudicate federal law issues. Thus, in Chick Kam Choo v. Exxon Corp., ${ }^{304}$ the Court determined that although federal injunctive relief is warranted for any issues which "actually have been decided" by the federal court, "a federal court does not have inherent power to ignore the limitations of $\S 2283$ and to enjoin state court proceedings merely because these proceedings interfere with a protected federal right or invade an area preempted by federal law.' ${ }^{305}$ Moreover, the Court in Chick Kam Choo affirmed that the Texas state courts "are presumed competent to resolve" the pre-emptive force of federal maritime law. ${ }^{306}$ Similarly, the

${ }^{303}$ See supra notes 292-94 and accompanying text (discussing the Vendo court's caution against any relaxation of the strict standards for determining the propriety of a federal injunction).

${ }^{304} 486$ U.S. 140 (1988).

${ }^{305}$ Id. at 148-49 (quoting Atlantic Coast Line R.R. Co. v. Brotherhood of Locomotive Eng'rs, 398 U.S. 281, 294 (1970)).

${ }^{306} \mathrm{Id}$. at 150. 
Court in Rivet ruled that a claim preclusion defense based on a prior federal judgment "is a defensive plea that provides no basis for removal under $\S 1441(\mathrm{~b})$ " and that "[s] uch a defense is properly made in the state proceedings. ${ }^{307}$

Federal intervention may be more frequently warranted when a Type I case is involved-that is, where there is a threat to a prior judgment but no preclusion determination to be made. Similarly, when a plaintiff's claims have actually been litigated in and disposed of by a federal court, and the plaintiff then seeks to relitigate those same issues in state court, Chick Kam Choo squarely supports the issuance of an injunction to preserve a validly-obtained judgment to prevent relitigation of issues previously decided.

By creating categories of cases, and interpreting the existing legal rules and judicial doctrines as they apply to each kind of case, we may focus on the underlying reasons why different kinds of cases are treated differently. For this analysis, we can consider the important work of Professor Douglas Laycock, whose thorough empirical study of the irreparable injury rule revealed that the traditional formula for determining whether to grant equitable relief is no longer applicable. ${ }^{308}$ Professor Laycock examined the traditional notion that the law prefers awarding legal relief-damages-over granting equitable relief. $^{309}$ His study revealed that courts do not demonstrate a preference for awarding legal relief. Instead, "[c] ourts have escaped the irreparable injury rule by defining adequacy in such a way that damages are never an adequate substitute for plaintiff's loss." ${ }^{310}$ Accordingly, Laycock concluded "that the irreparable injury rule is dead. It does not describe what the cases do, and it cannot account for the results." ${ }^{311}$ His study is particularly important in the context under examination here, where a federal court's judgment is being threatened by subsequent state litigation. In the interjurisdictional context, Laycock identified many of the policy reasons which typically are cited as justification for a court's decision to enter equitable relief. ${ }^{312}$ These include

\footnotetext{
${ }^{307}$ Rivet v. Regions Bank, 522 U.S. 470, 478 (1998).

${ }^{30 s}$ See DOUGLAS LAYCOCK, THE DEATH OF THE IRREPARABLE INJURY RULE 4 (1991) (arguing that "our legal system does not prefer damages").

${ }^{309}$ See $i d$. at 3-4 ("This rule says that equitable remedies are unavailable if legal remedies will adequately repair the harm.").

${ }^{310} I d$. at 4.

${ }^{311} I d$. at 5.

${ }^{312}$ See id. at 133-59 (examining the justification of deference to other authority).
} 
the following reasons: to prevent a multiplicity of suits; ${ }^{313}$ to ensure that a plaintiff is not procedurally or tactically disadvantaged by having to seek other relief (a concern that arises most commonly when the plaintiff seeks to enforce a previously bargained for settlement) $;^{314}$ to "enjoin harassing, repetitive litigation"; ${ }^{315}$ to ensure in the most efficacious manner possible the finality of judgments (often cited as justification for preventing the "relitigation of issues already decided"). ${ }^{316}$ Laycock observed that courts invoke these-and other-justifications for issuing equitable relief, including injunctive relief, in order to establish that damages are not "an adequate remedy." In other words, these are some of the compelling policy reasons that have prompted courts to intervene in the sovereign proceedings of other courts. Thus, by helping elucidate many of the actual reasons why courts may grant injunctive or other equitable relief, Laycock's work mày bring us closer to an informed assessment of when injunctive relief under the All Writs Act may be appropriate.

Consider, for instance, the appropriateness of issuing injunctive relief to stop a vexatious litigant from continuing to abuse the judicial process. This is precisely the situation the Ninth Circuit confronted in Wood v. Santa Barbara Chamber of Commerce, Inc. ${ }^{317}$ In Wood, the plaintiff appealed "from the grant of a permanent injunction prohibiting him from bringing any similar suit in any court. ${ }^{\text {,318 }}$ The plaintiff, a photographer, had initiated an action ten years earlier, alleging misappropriation of photographs he had taken. ${ }^{319}$ After several of his earlier actions were consolidated, the plaintiff commenced a new action in federal district court of Nevada against 253 defendants. ${ }^{320}$ While that case was pending, however, the plaintiff apparently initiated 35

${ }^{313}$ See id. at 139 (asserting that courts will enjoin wrongs "for which the legal remedy might require a multiplicity of suits").

${ }^{314}$ See id. ("[C]ourts will enjoin breach of settlement agreements, arbitration agreements, or other wrongs that deprive an opposing litigant of legitimate procedural advantage.").

315 Id.

316 Id.

${ }^{317} 705$ F.2d 1515 (9th Cir. 1983).

${ }^{318} I d$. at 1518.

${ }^{319}$ See id. ("This appeal is the latest installment of ten years of litigation concerning photographs that were taken by the appellant in $1968 \ldots .$. ).

${ }_{320}$ See id. ("He named 253 defendants, including the Santa Barbara Chamber of Commerce and every newspaper, magazine and publishing company carrying any advertising containing photographs taken by Wood for the Chamber of Commerce."). 
separate actions in 30 different jurisdictions. ${ }^{321}$ The district court then dismissed all claims against all defendants and entered a permanent injunction against the plaintiff from filing similar litigation. ${ }^{322}$ The Ninth Circuit affirmed the issuance of the permanent injunction, finding that the district court possessed authority under the All Writs Act to issue "an injunction against repetitive litigation. ${ }^{323}$ The court of appeals observed that the plaintiff "has shown his intention continually to relitigate claims that have been previously dismissed." ${ }^{324}$ The court then recognized the many advantages to the judicial system of employing injunctive relief to thwart a vexatious litigant:

One advantage of dispensing injunctive relief against relitigation is that it is an easy way to articulate forcefully the principles of collateral estoppel and res judicata. For the judicial system, this means a preservation of judicial resources. By describing the principles of collateral estoppel in mandatory terms and by reinforcing those principles with the threat of holding a vexatious litigant in contempt of court, a district judge may deter the filing of frivolous and repetitive lawsuits. ${ }^{32}$

Injunctive relief also serves the harassed defendant well:

For the victorious litigant, obtaining an injunction against relitigation provides an expedient method of asserting collateral estoppel. Armed with an injunction against relitigation, the successful litigant need not convince a new judge that the action pending before him is similar to and estopped by an earlier judgment.

The court quickly cautioned, though, that injunctions against relitigation should not be "used too freely or couched in overly broad terms" because they might "block free access to the courts." ${ }^{327}$ Yet, the relitigation injunction was appropriate in Wood not only because it ensured that the successful defendants would not have to relitigate the same issues, but precisely because "the history of this case shows that such future attempts are highly likely.... [The plaintiff] has clearly shown to this court and to the district court that, unless enjoined, he will continually attempt to renew his conflict ....,328

\footnotetext{
${ }^{321}$ See id. at 1523 (explaining the sequence of the plaintiff's various suits).

${ }^{322}$ See id. (describing the effects of the order entered by the district court).

${ }^{323}$ Id. at 1524.

${ }^{324} \mathrm{Id}$.

325 Id.

${ }^{326} I d$.

${ }^{327}$ Id. at 1525 .

${ }^{328}$ Id.
} 
Vexatious litigation may be one circumstance, therefore, warranting federal injunctive relief rather than reliance on the state courts to dismiss each and every new suit commenced. In this context, we can also reconsider the situation facing the Second Circuit in Yonkers. Although I have criticized the court's approval of use of the All Writs Act as an independent source of removal jurisdiction, Yonkers is a case in which injunctive relief-not removal-would have been the appropriate remedy. Recall that the court of appeals in Yonkers particularly doubted whether the City of Yonkers, "a reluctant condemnor, which at every opportunity has resisted implementation of the Housing Remedy Order, could be counted on in state court to adequately protect the integrity of the Consent Decree. ${ }^{, 329}$ In the court's assessment, the City of Yonkers could not be trusted to prosecute the state court condemnation proceeding vigorously. ${ }^{330}$ Without a sincere commitment by the City of Yonkers to prosecute the state condemnation proceedings, the constitutional rights of the plaintiffs, as vindicated by the federal order, could not be guaranteed. ${ }^{331}$

\section{CONCLUSION}

Examination of the existing legal rules and judicial doctrines that may be relevant when a federal judgment is implicated in subsequent state proceedings is not meant to suggest that a single, bright-line rule can be enacted to guide courts and litigants in all federal-state interjurisdictional cases. Such a goal is surely unattainable. The Court's and Congress's inability to articulate clear guidelines in this area is structural, reflecting the unassailable truth that a precise allocation of state and federal rights has not been accomplished. It is quite unimaginable that state and federal rights could ever be balanced precisely through the enactment of general rules and doctrines. Courts must treat different cases differently, depending on their particular circumstances; and the relevant legal authorities must be applied in each instance. (Even the determination of which authorities are relevant may vary from case to case.)

Nevertheless, recognition of the difficulties inherent in enacting

${ }^{329}$ Yonkers Racing Corp. v. City of Yonkers, 858 F.2d 855, 865 (2d Cir. 1988).

${ }^{330}$ See id. ("To believe otherwise would be to ignore the fact that Yonkers entered into the Consent Decree and instituted the condemnation proceedings only after being threatened by the district court with sanctions for contempt.").

${ }^{331}$ See id. (" $[R]$ emoval was necessary to protect the integrity of the Consent Decree (..."). 
and applying the governing rules and doctrines does not mean that attempting to understand those rules and doctrines is not a worthwhile and important goal. To the contrary, seeking greater clarity is important on several levels. First, and most relevant to our current study, a better understanding of how the existing legal authorities are to be applied to determine the appropriateness of federal intervention helps illustrate that the practice by several circuit and district courts of upholding removal of state cases by the All Writs Act is unwarranted. It is unwarranted precisely because neither the Court nor Congress has approved intervention in state court proceedings in this manner. Courts and litigants must turn to the existing legal rules and judicial doctrines to answer when and whether a federal court may enjoin state proceedings. When a court upholds removal of a state case on the authority of the All Writs Act, an ill-defined "exceptional circumstances" measure is substituted for the existing rules and longstanding judicial doctrines.

Beyond this, and on a more general level, greater clarity in understanding the currently existing authorities-how they interact, and on what policy principles they are grounded-may yield a better appreciation for when federal intervention in state proceedings is appropriate. Proponents of deference will cite such decisions as Rivet as supporting authority, while those seeking justification for federal intervention into state proceedings will rely more heavily on the exceptions to the Anti-Injunction Act. The courts must decide in each case whether the importance of deference is outweighed by the necessity of federal intervention to protect and effectuate a prior federal judgment. Deference may be warranted in a majority of cases in which a prior federal judgment is implicated, particularly when the state court is fully capable of adjudicating the federal law issues and protecting the prior federal judgment, and where the parties possess an incentive to effectuate the federal judgment. Yet, cases in which federal intervention to protect and effectuate a prior federal judgment is unavoidable will continue to arise. Permitting federal courts to expand the scope of removal jurisdiction by resort to the All Writs Act only distorts the analysis for determining when intervention is appropriate. Properly limited, the All Writs Act would not be invoked as a source of removal authority. The All Writs Act can and should be used as a source for granting injunctive relief when application of the existing legal rules and judicial doctrines reveals that intervention is necessary. Whether a state court should be left alone to determine the preclusive effects of a prior federal judgment, or to adjudicate a 
case in which a prior federal ruling is implicated, is to be decided by application of these existing legal rules and judicial doctrines, not by resort to the All Writs Act to uphold a defendant's removal of the state case to federal court. 
